\title{
Arus Baru Kecenderungan Penafsiran Kontemporer
}

\author{
Musholli Ready ${ }^{1}$
}

\begin{abstract}
This article discusses the modern trends in Qur'anic interpretation: the hermeneutical approach and the thematic one. It will first elaborate the origin of hermeneutics, how it has been used by many Muslim scholars, and why many Muslims regarded negatively to this approach. The article then discusses the second approach which is the most used in the Qur'anic interpretation, because, this article argues, it has many advantages, compared to the previous one. At the end, this article proposes the integration between the two approaches.
\end{abstract}

Keywords: hermeneutics, author centered interpretation, reader centered interpretation, tafsir maw $\bar{u} \bar{u}$ ' $\overline{\text {, }}$ istantiq al-Qur'ān

\section{Pendahuluan}

Tulisan ini membuktikan bahwa ada dua kecenderungan baru yang dominan, digunakan oleh para intelektual muslim dalam mengkaji atau menafsirkan al-Qur'ān yaitu pendekatan hermeneutik dan metode tematik. Ditengarai bahwa pendekatan hermeneutik adalah pendekatan yang lahir dari rahim Barat, sementara metode tematik lahir dari tradisi Islam, terutama dari pemikir Timur Tengah. Namun demikian, kedua pendekatan tersebut akan sangat menarik dan bermanfaat apabila mampu diintegrasikan sehingga tujuan al-Qur'ān mampu dikejewantahkan.

Pendekatan yang digunakan dalam tulisan ini adalah pendekatan komparatif membandingkan antara hermeneutika, tafsir bi al-ma'th $\overline{u r}$ wa tafsir bi al-ra'y, serta pendekatan tematik. Ia juga menggunakan pendekatan historis untuk menjelaskan geneologi dan perkembangan masing-masing pendekatan.

Artikel ini diawali dengan pembahasan mengenai hermeneutika, lalu perbedaannya dengan tafsìr bi al-ma'thür dan tafsìr bi al-ra'y, dan dilanjutkan dengan pembahasan tafsir tematik. Di akhir artikel, integrasi antara pendekatan hermeneutika dan tematik ditawarkan sebagai pendekatan alternatif.

${ }^{1}$ Dosen Institut Agama Islam Nurul Jadid Paiton Probolinggo Jatim. Alamat: Paiton Probolinggo Jatim. E-mail: mullareza@ymail.com 


\section{Hermeneutika: Trend Baru Penafsiran Kontemporer ${ }^{2}$}

Dalam upaya mengembalikan al-Qur'ān sebagai kitab petunjuk (hudan li al-nās), para mufassir kontemporer berpandangan bahwa al-Qur'ān adalah kitab suci yang tidak lagi dipahami sebagai sesuatu yang mati, namun al-Qur'ān adalah kitab suci yang hidup. Menurut para mufassir kontemporer, al-Qur'ān adalah kitab suci yang kemunculannya tidak terlepas dari konteks kesejarahan umat manusia. Al-Qur'ān diturunkan bukan dalam hampa budaya, namun datang dan diwahyukan dalam zaman dan ruang yang sarat budaya. Meminjam istilah Nașr Hāmid Abū Zayd (1. 1942) bahwa al-Qur'ān adalah "produk budaya" yaitu teks (al-naș F) yang muncul dalam sebuah struktur budaya Arab abad ketujuh selama lebih dua puluh tahun dan ditulis dengan berpijak pada aturan-aturan budaya Arab ${ }^{4}$

${ }^{2}$ Teori periodesasi klasik (al-qadim), pertengahan (al-wast), modern (al-hadith) dan kontemporer (al-mu'ạșir), penulis menggunakan teori kombinasi yaitu periodesasi yang dibangun oleh M. Howard Federspiel, Harun Nasution dan Kautsar Azhari Noer: klasik yaitu dimulai dari 650 hingga $1250 \mathrm{M} / 71-674 \mathrm{H}$, pertengahan dimulai dari 1250 hingga $1800 \mathrm{M} / 674-1221 \mathrm{H}$, sementara abad modern berawal dari 1800-1970 M/1221$1391 \mathrm{H}$ dan kontemporer dimulai dari 1970-/1391 hingga sekarang. Harun Nasution, Islam Rasional: Gagasan dan Pemikiran Prof. Dr. Harun Nasution, cet. V (Jakarta: Mizan, 1998), 7. Sementara periodesasi kontemporer penulis ambil dari pendapat Kautsar Azhari Noer yang mengatakan bahwa zaman kontemporer adalah era kekinian yaitu yang semasa dengan kita. Pemaknaan ini ada benarnya karena makna kontemporer dalam istilah arabnya adalah al-mu'assir (semasa, seangkatan, dewasa ini). Bandingkan periodesasi ini dengan Faried F. Saenong, "Kodifikasi Ulum al-Qur'ān hingga Abad Pertengahan: Studi Bibliografis," dalam Jurnal Studi al-Qur'ān Vol I No I Januari 2006 (Jakarta: Lentera Hati), 111. Bandingkan pula dengan Howard Federspiel, Kajian alQur'ān di Indonesia (Jakarta: Mizan, 1996), 82-93. lihat juga Kautsar Azhari Noer, "Aliran-aliran Islam Kontemporer," Makalah Mata Kuliah Analisa Pemikiran Islam Kontemporer Mahasiswa Sekolah Pascasarjana UIN Syarif Hidayatullah, 16-09-2008, 1.

3 Pemahaman al-Qur'ān sebagai teks mendapatkan respon keras dari ulama alAzhar. Menurut mereka, al-Qur'ān, sunah dan perkataan sahabat nabi tidak pernah menggunakan penggunaan kata teks (nașs) yang merujuk pada al-Qur'ān. Mereka berpandangan bahwa al-Qur'ān, hanya menyebut dirinya dengan nama al-mușhaf, alkitāb dan lain sebagainya. Penggunaan kata teks yang dilekatkan pada al-Qur'ān adalah suatu bid'ah. Lihat Moh. Nur Ichwan, "Al-Qur'ān sebagai Teks (Teori Teks dalam Hermeneutika al-Qur'ān Naṣr Ḥāmid Abū Zayd)," dalam Abdul Mustakim dan Sahiron Syamsuddin (ed), Studi Al-Qur'ān Kontemporer, Wacana Baru berbagai Metodologi Tafsir (Yogyakarta: Tria Wacana, 2002), 147-148.

${ }^{4}$ Abū Zayd mengatakan sebagaimana yang dikutip oleh M. Nur Ichwan:" I treat the Quran as the texs in the Arabic linguage to be studied by muslim, Christians and Atheists alike”. Statement mempunyai tiga pengertian, pertama Al-Qur'ān adalah sebuah teks, terutama sebuah teks linguistik, dan pasti, bahasa tidak bisa dipisahkan dari budaya dan sejarah: kedua mengkaji teks harus menggunakan pendekatan linguistik dan sastra yang memperhatikan aspek-aspek kultural dan historis teks. Dan ketiga, titik berangkatnya bukan dari keimanan akan tetapi objektifitas keilmuan sehingga baik muslim atau non muslim dapat memberikan kontribusi terhadap kajian al-Qur'ān. Lihat 
Jika demikian, maka untuk memahami al-Qur'ān tidak cukup hanya mengandalkan perangkat keilmuan seperti yang digunakan oleh para mufassir selama ini semisal ushul fiqh, asbabun nuzul, nahwu sorof, balaghah dan lain sebagainya. Namun, harus dilengkapi dengan perangkat atau piranti-piranti yang mampu memberikan dan menemukan satu solusi dalam rangka menemukan jawaban problematika yang menjerat umat muslim saat ini. ${ }^{5}$

Pilihan itu, akhirnya jatuh pada pendekatan hermeneutika yang menurut hemat para mufassir kontemporer mampu menjadi menu alternatif, bagi perangkat keilmuan yang selama ini telah banyak menyumbangkan bagi peradaban keilmuan Islam. Metode hermeneutika yang dikembangkan oleh para mufassir kontemporer juga beragam. Keberagaman ini merupakan bukti konkrit bahwa inklusifitas umat Islam terhadap keilmuan dan gagasan atau metode dari luar semakin nyata dan menemukan momentumnya. ${ }^{6}$

Muh. Nur Ichwan, Meretas Kesarjanaan al-Qur'an, Teori Hermeneutika Nașr Hāmid Abu Zayd (Jakarta: Teraju, 2003), 67. Lihat Nașr Hāmid Abū Zayd, Mafhūm al-Nāṣs : Dirāsah fì 'Ulūm al-Qur'ān (Kairo: al-Hay'ah al-Mișriyah al-'Ammah li al-Kitāb, 1993), 27-28. Abdul Mustaqim, Aliran-Aliran Tafsir: Madzahibut Tafsir dari Periode Klasik hingga Kontemporer (Yogyakarta: Kreasi Wacana, 2005), 80.

'Lihat Adnin Armas, Metodologi Bibel dalam Studi al-Qur'ān (Jakarta: Gema Insani Press, 2006), 72. Bandingkan dengan Nasaruddin Umar, "Menimbang Hermeneutika Sebagai Manhaj Tafsir," dalam Journal Studi al-Qur'ān Vol I, No 1, Januari 2006, (Jakarta: Yayasan Lentera Hati, 2006), 46.

${ }^{6}$ Menarik untuk dipertimbangkan, ketika imam al-Shāfi'i (150-204 H/767-820 M) menjawab pertanyaan Harun al-Rashid (168-191 H/786-809M.) tentang keahliannya, ia menjawab bahwa pengetahuannya meliputi ilmu kedokteran sebagaimana apa yang dirumuskan oleh bangsa Romawi seperti Aristoteles (384-322 SM), Porporius, Epicurus, dan Galenus serta yang lain-lain. Lebih jauh Sāmi Nashshār menduga bahwa teori qiyas imam al-Shäfi' $\bar{i}$ terpengaruh oleh teori silogisme Aristoteles. Dalam bidang ilmu kalam (ilmu tauhid), ada banyak persinggungan dengan pemikiran-pemikiran luar Islam khususnya kebudayaan Yunani seperti filsafat. Memang, kelahiran ilmu kalam berawal dari pergolakan politik dan kekuasan paska wafatnya nabi Muhammad, tapi pada perkembangan selanjutnya ilmu kalam dan filsafat berkelindan bahkan saling melengkapi satu sama lainnya. Logika sebagai salah satu cabang dari ilmu filsafat sudah merupakan salah satu komponen yang mutlak harus dipahami dalam mempelajari ilmu kalam. Jika memang demikian fakta historisnya, ironi sekali ketika muncul sebuah paham yang menolak keras hermeneutika sebagai salah satu disiplin keilmuan atau teori dalam menafsirkan al-Qur'an. Lihat 'Alì Sāmi Nashshār, Manahaj al-Bahth 'ind Mufakkirí alIslām (Beirut: Dār al-Nahḍah al-Arabiyah,tt), 85. Lihat juga Fahruddin Faiz, Hermeneutika al-Qur'ān: Tema-tema Kontroversial (Yogyakarta: eLSAQ Press, 2005), xv-xvii.

Abū Hāamid al-Ghazāli (w.1111) pernah menyatakan"Inna man la yuhịtu bilMantiq falā thiqata bi "ulümhi așlan" (siapa saja yang tidak memahami ilmu mantiq, ilmunya tidak dipercaya sama sekali). Pendapat ini mendapat kecaman keras dari Ibn Șalāh dan mengharamkan seseorang untuk mempelajari logika. Anehnya, hampir bisa dipastikan setiap pondok pesantren, baik salaf(klasik) atau khalaf(modern) di Indonesia, ilmu mantiq dijadikan mata pelajaran pendidikan. Di dalam menemukan konklusi 


\section{Hermeneutika sebagai Sekularisasi Penafsiran Kitab Suci.}

Hermeneutika, sekalipun istilah ini sejak lama telah dikenal dalam tradisi Yunani kuno, sebagai sebuah konsep tentang penafsiran kitab suci. Puncak perkembangan hermeneutika sebagai penafsiran terhadap kitab suci muncul pada masa reformasi. Sebagaimana diketahui bahwa agama Kristen terpecah dalam dua kelompok yang disebabkan karena perbedaan prinsip penafsiran. Dalam melawan otoritas gereja Katolik, para reformis mengajukan prinsipprinsip kejelasan dan kemandirian kitab suci.

Mattias Flacius Illiyricus (1520-1575 M) dalam bukunya Clavis Scripturae Sacrae Seu de Sermone Sacrarum Litterarum, menyatakan bahwa jika injil tidak bisa dipahami secara tepat, hal itu tidak berarti bahwa gereja-lah yang mempunyai otoritas tunggal dalam memahami kitab Injil, akan tetapi disebabkan oleh kekurang cukupan pengetahuan yang dimiliki oleh penafsir. Di sisi lain, Injil diyakini memiliki satu koherensi dan kontinuitas internal sehingga pembacaan terhadap injil harus dibawah sorotan Injil secara keseluruhan. ${ }^{7}$

Dalam perkembangan selanjutya, hermeneutika tidak hanya terbatas menafsirkan kitab suci akan tetapi juga difungsikan untuk menafsirkan teksteks sekular. Hal ini seiring dengan perkembangan disiplin filologi di abad pertengahan. Bangkitnya interest terhadap teks-teks klasik dari Yunani telah menciptakan gudang kritik filologi yang bertujuan untuk mendapatkan otentitas teks dan untuk merekontruksi sebaik mungkin versi yang asli dan benar. Dalam disiplin ini, semua teks diberlakukan sama, sebagaimana yang dikatakan August Ernesti bahwa pemahaman secara verbal terhadap kitab suci harus tunduk dibawah aturan yang sama dengan yang dilakukan terhadap teks lain. Sejak saat itu, kerja hermeneutika yang pada mulanya hanyalah sebuah konsep yang berhubungan dengan teks suci diperluas wilayah kerjanya. Ini juga membawa konsekwensi radikal yaitu bersentuhannya kitab suci dengan teori-teori penafsiran sekular seperti filologi klasik tersebut."

Sekalipun demikian, tokoh yang bisa disebut sebagai bapak hermeneutika modern adalah F.D.E. Schleiermacher $(1768-1834)^{9}$. Dan pada

keyakinan tentang wājibul wujūd-Nya Tuhan, penafsir bersinggungan dengan daur dan tasalsul yang metode konklusnya (natijah) menggunakan teori logika. (Sullamul Munawwar (Surabaya: Al-Hidayah,tt), 3.

${ }^{7}$ A. Zainul Hamdi, "Hermeneutika Islam: Intertekstualitas, Dekontruksi dan Rekontruksi," dalam Journal Gerbang Vol V no 14, 2003, 55. Bandingkan dengan Armas, Metodologi Bibel dalam Studi al-Qur'ān, 35-41.

56.

${ }^{8}$ Hamdi, "Hermeneutika Islam: Intertekstualitas, Dekontruksi dan Rekontruksi,"

${ }^{9}$ Pada awal kebangkitannya kembali di zaman modern, hermeneutika dikenal sebagai gerakan exegesis di kalangan geraja. Adalah Schleiermacher yang dikenal sebagai bapak hermeneutika modern yang pertama kali membakukan hermeneutika 
perkembangannya, hermeneutika setidaknya bisa dipetakan dalam dua kecenderungan: pertama hermeneutika yang berpusat pada pengarang (authorcentered hermeneutics) ${ }^{10}$, dan kedua hermeneutika yang berpijak pada penafsir (reader-centered hermeneutics) $^{I I}$

\section{Hermeneutika dalam Kajian Keilmuan Islam}

Ketika seseorang membaca semisal sebuah teks musalli yușalli fi $\bar{i}$ almusallā dan mencoba memahami sebuah makna yang terkandung di dalamnya, tentu akan bervariasi dalam menafsirkan dan menangkap maknanya. Bagi sementara orang, teks tersebut mungkin begitu mudah untuk dipahami dan dicerna, tapi tidak demikian bagi orang lain. Bisa jadi teks tersebut menjadi rumit untuk dipahami, ia harus berfikir keras dan cerdas untuk memahami teksteks sebelumnya. Ia mesti membuka-buka karya-karya terdahulu yang berkenaan dengan teks itu, mencari informasi historis dan mencari korelasi dengan teks-teks lainnya sehingga mampu menangkap makna didalamnya.

Apakah dua kondisi pembaca atau penafsir ini bisa disimpulkan bahwa kondisi pertama tidak membutuhkan hermeneutika dan kondisi kedua membutuhkannya? Ternyata jawabannya tidak mesti demikian. Hermeneutika tidak hanya berkutat pada seputar teks yang sulit untuk dicerna. Bagi Schleiermacher (1768-1834) hermeneutika lebih detail mempertanyakan dan meragukan dengan penuh kesadaran tentang keabsahan penangkapan pembaca terhadap pesan atau makna yang terkandung dalam teks tersebut. Apa yang menjamin pemahaman terhadap teks sederhana itu benar? Bukankah ada jarak antara penafsir (interpreter) dengan yang mengarang teks itu (the author)? Apakah bahasa oral atau tulisan yang dijadikan medium dapat melambangkan

sebagai metode umum penafsiran yang tidak hanya terbatas pada kitab suci dan sastra. Kemudian dilanjutkan oleh Dilthey yang menerapkannya sebagai metode sejarah dan dikembangkan oleh Gadamer menjadi filsafat. Paul Ricoeur menjadikannya sebagai metode penafsiran fenomenologis-komprehensif. Lihat Fahruddin Faiz, Hermeneutika alQur'ān, 6. Bandingkan dengan E. Sumaryono, Hermeneutik: Sebuah Metode Filsafat (Yogyakarta: Kanisius, 1999). Bandingkan pula dengan Armas, Metodologi Bibel dalam Studi al-Qur'ān, 42-43.

${ }^{10}$ Model hermeneutika ini merupakan salah satu piranti yang diadopsi oleh Fazlur Rahman dalam memahami al-Qur'ān dengan menggunakan metode gerakan ganda (Double Movements). Lihat Tamara Sonn,"Fazlur Rahman”, dalam John L. Esposito (ed), The Oxford Encyclopedia of the Modern Islamic Word, vol. 3 (Oxford University Press, 1995), 408, dan Fazlur Rahman, Metode dan Alternatif NeoModernisme Islam, terj. Taufik Adnan Amal, 55-56. Lihat juga Ali Mansur, "Ahli Kitab dalam Al-Qur'ān (Model Penafsiran Fazlur Rahman)" dalam Abdul Mustakim dan Sahiron Syamsuddin (ed.), Studi Al-Qur'ān Kontemporer, Wacana Baru berbagai Metodologi Tafsir (Yogyakarta: Tria Wacana, 2002), 48.

${ }^{11}$ Katagorisasi ini, penulis ambil dalam makalah Yusuf Rahman dengan judul "Hermeneutika dan al-Qur'ān" dalam bentuk soft copy. 
secara akurat maksud penulis atau pengarang? Keraguan-keraguan semacam inilah yang menjadi pemikiran dan renungan para pemikir hermeneutika. ${ }^{12}$

Sebenarnya, jika menelisik sejarah peradaban keemasan Islam (the golden age of Islam), tepatnya pada abad ke 7-12, keraguan atau pertanyaan terhadap pemahaman teks seperti di atas telah ada. Hal ini bisa dilihat dalam konsep muhkam, mutashābihāt dan majāz. Para ulama sudah mulai mempertanyakan bagaimana penangkapan makna yang akurat terhadap maksud Allah yang tertuang dalam al-Qur'ān. Bagaimana ayat-ayat hukum seperti kata al-qurū dalam surah al-Baqarah (2): 228. Menurut ulama kata yang terkandung dalam ayat muhkam bisa multi makna, sehingga melahirkan konsep hukum yang berbeda pula. ${ }^{13}$

Mutashābihāt adalah ayat-ayat yang masih samar dan menyita otak untuk menangkap makna yang terkandung, seperti kata istawā dalam QS. Thāha (20): 5. Kubu salafi memaknai bahwa Allah bertahta di Arash dengan tanpa ada pertanyaan kaifa (bagaimana). Ini berbeda dengan kelompok rasionalis yang menafsirkan bahwa istawā dimaknai Allah menguasai Arash, bukan bertahta di Arash karena Allah tidak bersinggungan dengan ruang dan waktu. Penafsiran majāzi (metaforis) dilakukan ketika makna haqiqi (sejati) sudah tidak memberikan pertolongan pertama yang mujarab terhadap kecelakaan yang dialami oleh teks, sehingga diperlukan penggeseran, dan kalau perlu banting setir untuk menemukan makna yang dimaksud. ${ }^{14}$

Abū Ubaidah (w.210/828) memberikan definisi yang cukup jelas bahwa majāz adalah berlari meninggalkan makna asal (al-waḍ al-awwal) hijrah menuju makna baru (al-wad̆ al-thānì). Sekedar menghilangkan kehausan akan polemik majāzi, Abū Ubaidah memberikan contoh sebagai berikut : "apabila engkau akan membaca (qara'ta) sebagian dari ayat-ayat al-Qur'ān (al-Qur'āna) maka bacalah ta'awwudh (mohon perlindungan) kepada Allah dari setan yang terkutuk”(QS. Al-Nahl : 98).

\footnotetext{
${ }^{12}$ Lihat Muḥ. 'ATi al-Riḍā'i al-Așfahānī, Manahij al-Tafsì̄ wa Ittijāhuh : Dirāsah Muqaranah fì Manahij Tafsìr al-Qur'ān al-Karim (Beirut: Markaz al-Haḍarah liTanmiyati al-Fikri, 2007), 402. Bandingkan dengan Naṣr Ḥāmid Abù Zayd, Hermeneutika Inklusif. Ter. Muh. Mansur, dkk. (Jakarta: ICIP, 2004), 14.

${ }^{13}$ Sayyid Sābiq, Fiqh al-Sunnah, Vol II (Kairo:Dār al-Qalam, 1995), 343. Mengenai ragam makna dalam satu kata, Muhammad 'Alwi al-Malaki mengurai dengan detail tentang makna al-Hudā, yaitu sebagai berikut 1) tetap (al-thabāt), 2) terang (albayān), 3) agama (al-dìn), 4) kepercayaan (al-ïmān), 5) meyatukan (al-tauhịd), 6) jejak (al-sunnah), 7) ilham (al-ilhām), 8) taubah (al-Taubah). Lihat Muhammad 'Alwi alMalikī, al-Qawā'id al-Asāsiyyah fì 'Ulüm al-Qur'ān (Mekkah: Maktabah Fahd, tt), 6061.

${ }^{14}$ Dari kalangan sahabat, 'Umar ibn Khațtāb sering kali tidak "mengindahkan" dan berseberangan dengan teks al-Qur'ān, semisal penagguhan hukuman potongan tangan, dan penundaan pemberian zakat terhadap para muallaf.
} 
Ayat di atas terpampang jelas bahwa kata fi'l mạdi (past tense) yaitu qara'ta hijrah menjelma makna fi' 1 muḍ̄ari ' (present countinous/future) yaitu sataqra'. Di samping itu, kata al-Qur'ān ternyata tidak dimaknai semua ayat alQur'ān namun bermakna sebagian dari ayat-ayat al-Qur'ān. Makna-makna yang berbelok haluan ini dimaksudkan untuk mencapai makna tujuan yang akurat sehingga pesan terkuak dengan jelas. ${ }^{15}$

Cuplikan contoh di atas mengilustrasikan bahwa hermeneutika sebagai sebuah teori dan metode penafsiran telah ada dalam ruang kerja ilmu tafsir yang salah satu unsur pembahasannya adalah tentang linguistik dan gramatikal. ${ }^{16}$

Mengutip pendapat Schleiermacher, sebuah kerja penafsiran menuntut pada pembaca untuk berusaha "reliving and re-thinking the thought and feelings of an author" yaitu agar penafsir berusaha untuk menempatkan dirinya pada posisi pemikiran, perasaan dari sang pengarang. Ini dimaksudkan untuk memperpendek jarak pisah antara dunia penafsir dan dunia pengarang. Memang tawaran ini sangat sulit diterapkan sebab begitu sebuah gerobak teks digelindingkan ke jalan raya realitas, ia akan berjalan mengikuti putaran roda gerobak di sepanjang jalan itu sehingga penafsirnya tidak mudah mengenal pengarangnya $^{17}$.

Schleiermacher menyatakan bahwa seseorang penafsir atau pembaca harus mampu memadukan aspek praktis dan teoritis dalam kerja-kerja hermeneutisnya. Lapisan pertama adalah metode hermeneutis dengan mengajukan seperangkat alat filosofis dan eksegetis yaitu kerangka rekontruksi gramatikal, historis dan komparatif. Lapisan kedua adalah kerangka teoritis yang disebutnya dengan istilah rekontruksi divinatoris, yaitu bagaimana seorang penafsir melakukan loncatan (jumping) dan memasuki dunia pengarangnya, baik dari aspek psikis, kultur dan lingustiknya. ${ }^{1{ }^{8}}$

Tokoh lain yang senada dengan Schleiermacher adalah Wilhelm Dilthey (1833-1891), yang mengatakan bahwa produk-produk budaya manusia hanya bisa didekati dengan Verstehen (mengerti). Suatu karya seni, misalnya bisa dimengerti dengan baik dengan cara mencemplungkan diri penafsir ke dalam sumur zaman historisnya atau melemparkan ke dalam kehidupan seniman yang

${ }^{15}$ Abū Ubaidah, Majāz al-Qur'ān, , 19.

${ }^{16}$ Machasin, "Sumbangan Hermeneutika terhadap Ilmu Tafsir," dalam Gerbang: Journal Studi Agama dan Demokrasi, Vol 5, No 14, 123. Bandingkan dengan Fahruddin Faiz, Hermeneutika al-Qur'ān, 7.

${ }^{17}$ Komaruddin Hidayat, Memahami Bahasa Agama, Sebuah Kajian Hermeneutik (Jakarta: Paramadina, 1996), 148.

${ }^{18}$ Maulidin, "Sketsa Hermeneutika," dalam Gerbang: Journal Studi Agama dan Demokrasi, Vol 5, No 14, 12. Lihat juga Schleiermacher "Foundation: General Theory and Art of Interpretation," dalam Kurt Muller-Vollmer (ed), The Hermeneutics Readers (New York: The Publishing Company, 2002), 86-87. 
bersangkutan. Verstehen adalah menemukan makna suatu produk manusia yang hanya dapat dimengerti dengan menempatkannya dengan konteknya. Untuk itu, Dilthey menyatakan bahwa diperlukan beberapa syarat untuk menjalankan roda kemengertian itu.

Pertama membiasakan diri dengan psikis-psikis yang memungkinkan terlahirnya suatu makna. Untuk mengerti makna berselingkuh, misalnya perlu diri sendiri mempuyai pengalaman tentang itu, syarat ini sebagian sudah terpenuhi karena setiap manusia mempunyai rasa itu tapi itu belum cukup representatif. Seseorang harus memperdalam juga studi biografi dan psikologi deskriftif. Kedua pengetahuan tentang konteks karena dengan mengetahui konteks suatu kata dapat dimengerti dalam kalimat atau dalam pengertian yang lebih jauh, bahkan suatu tindakan akan dimengerti secara menyeluruh. Ketiga pengetahuan tentang sistem sosial dan kultural yang menentukan gejala-gejala yang penafsir baca itu. Untuk mengetahui dan mengerti suatu kalimat, perlu diketahui bahasa yang bersangkutan ${ }^{19}$.

Apakah yang dapat dikonklusikan dari konsep hermeneutis yang dibangun oleh Schleiermacher dan Dilthey ini? Menurut mereka, mengerti suatu teks berarti menemukan arti yang asli dari teks itu. Sederhananya, interpretasi adalah menampilkan makna-makna yang dikehendaki oleh pengarang itu. Karena itu, lanjutnya, seorang penafsir harus menyimpan amunisi pengetahuan yang menggunung tentang sejarah, di samping juga psikologi sebagai bekal dalam petualangan penafsiran. Bagi Schleiermacher dan Dilthey, kerja interpretasi teks adalah merupakan pekerjaan reproduktif. Melompat pada masa lalu (jumping to the past) adalah suatu keniscayaan untuk menghayati peristiwa-peristiwa masa lalu yang tertimbun dalam gunung es teks atau yang berdarah-darah yang membanjiri areal teks. Gadamer menyebut konsep hermeneutika Schleiermacher dan Dilthey sebagai pandangan hermeneutik romantis, yaitu pandangan yang menandai zaman romantik (go back to the past).

Selanjutnya, teori hermeneutika dari dua tokoh ini ditelikung dan dihadang oleh Hans-George Gadamer (1900-2002). Memang, ia tidak menutup mata dari keunggulan-keunggulan hermeneutika romantis, tapi ia juga melihat ada bintik-bintik kelemahan di sana-sini. Bintik kelemahan yang pertama ialah bahwa hermeneutika bertugas menemukan dan menyusuri makna asli teks yang dituju. Bagi Gadamer tugas hermeneutika tidak hanya menemukan makna itu,

${ }^{19} \mathrm{~K}$. Bertens, Filsafat Barat Kontemporer: Inggris dan Jerman (Jakarta:Gramedia, 2002), 99. Bandingkan dengan Maulidin, "Sketsa Hermeneutika," 13-16. Dan lihat Wilhelm Dilthey, "The Hermeneutics of the Human Sciences," dalam Kurt MullerVollmer (ed), The Hermeneutics Readers (New York: The Publishing Company, 2002), 152. Juga lihat Naṣr Hāamid Abū Zayd, Hermeneutika Inklusif, 27-28. 
tetapi suatu interpretasi terhadap teks tetap terbuka dan tidak terbatas pada maksud si pengarang. ${ }^{20}$ Karenanya, kegiatan interpretasi bukan hanya reproduktif belaka tapi juga produktif. Ibarat para spekulan dan pialang saham, konglemaratisasi makna sebuah teks bisa dikukuhkan dan diperkaya dengan kegiatan bisnis interpretasi. $^{21}$

Bintik kelemahan kedua adalah pendapat hermeneutis romantis menyangkut waktu. Interpreter tidak mungkin melepaskan dirinya dari situasi historis di mana ia berada. Itu sama halnya dengan seseorang yang dicuci otaknya (brainstorming) kemudian diganti dengan memori masa lalu tanpa ada keterpengaruhan dari prasangka-prasangka yang mengawalinya dan kondisi sosial di mana ia mengerjakan proyek interpretasi. Akan tetapi teori Gadamer ini menyisakan pertanyaan yaitu bagaimana membedakan prasangka baik dan jelek? Dia kemudian menganjurkan untuk membangun sebuah gedung interpretasi yang berpijak dari kesadaran diri yang bersifat historis. Kesadaran ini akan membangunkan kesadaran prasangka-prasangka dan memungkinnya untuk mengisolasi dan menilai obyek di atas diri sendiri. Oleh sebab itu, lanjut Gadamer, interpretasi adalah kerja-kerja intelektual terhadap sebuah bangunan teks yang tidak pernah berujung dan tuntas. Setiap zaman harus menginterpretasikan teks untuk zamannya dan akhirnya suatu interpretasi definitif tidak bisa diharapkan ${ }^{22}$.

Lalu bagaimana dengan teks al-Qur'ān dan pengarangnya yang berada jauh melampaui teksnya? Bagaimana dengan teori Schleiermacher dan Dilthey yang menyatakan bahwa kerja interpretasi teks adalah merupakan pekerjaan reproduktif. Dan jika meminjam istilah Gadamer bahwa suatu interpretasi terhadap teks tetap terbuka dan tidak terbatas pada maksud si pengarang. Benarkah interpretasi adalah kerja-kerja intelektual terhadap sebuah bangunan teks yang tidak pernah berujung dan tuntas. Setiap zaman harus menginterpretasikan teks untuk zamannya dan akhirnya suatu interpretasi definitif tidak bisa diharapkan?

${ }^{20}$ Pertanyaan yang muncul kemudian adalah bolehkah teori dan konsep itu dipraktekan dalam kerja penafsiran terhadap teks-teks al-Qur'ān. Pembahasan ini akan saya pertajam dalam analisa tafsir bi al-ra'yi.

${ }^{21}$ Hamdi, "Hermeneutika Islam: Intertekstualitas, Dekontruksi dan Rekontruksi," 47. Lihat juga Abū Zayd, Hermeneutika Inklusif, 48-49. Lihat Slamet Warsidi, "Hermeneutika Dialektik Spekulatif Hans Georg Gadamer: Aktualisasi serta Relevansinya dalam Kajian Teks Keagamaan," dalam Journal Filsafat Potensia (Fakultas Ushuluddin Sunan Kalijaga Yogyakarta), 2002, 5-7.

${ }^{22}$ Hamdi, "Hermeneutika Islam: Intertekstualitas, Dekontruksi dan Rekontruksi," 47. Lihat juga Abū Zayd, Hermeneutika Inklusif, 48-49. Lihat Slamet Warsidi, "Hermeneutika Dialektik Spekulatif Hans Georg Gadamer," 5-7. Bandingkan dengan K. Bertens, Filsafat Barat Kontemporer: Inggris dan Jerman (Jakarta:Gramedia, 2002), 263. 


\section{Tafsìr bi al-Ma'thür dan Tafsìr bi al-Ra'y}

Dalam ilmu tafsir, ada banyak metode, bentuk dan corak penafsiran yang variatif. Bentuk penafsiran itu dikenal dengan istilah: pertama adalah tafsir bi al-ma'thüryaitu tafsir yang berdasarkan pada tradisi (sunnah) kenabian. Metode ini dilakukan sebagai sebuah teori alternatif mengingat Allah di luar jangkauan analisa ilmiah-empiris. Tak ayal peran pengarang al-Qur'ān digantikan oleh orang yang menerima mandat teks tersebut yaitu nabi Muhammad Saw (571$632 \mathrm{M}$ ). Teori ini berpandangan bahwa nabi Muhammad mempunyai otoritas tertinggi untuk menjelaskan pesan-pesan Tuhan yang tersurat atau tersirat.

Ini menandakan bahwa orang yang bisa memahami maksud pesan Tuhan hanyalah nabi Muhammad saw. dan orang yang sezaman dengannya. Orang yang di luar zaman itu tidak bisa memaknai pesan-pesan Tuhan dengan baik karena teks diproduksi dalam suasana tertentu (li al-zamān wa al-makān almakhsūsusah) dan oleh subjek (Rasulullah) yang mempunyai sudut pandang tertentu pula serta terhadap objek tertentu pula (sahabat). Terdapat pula keyakinan bahwa yang bisa memahami teks al-Qur'ān dengan baik adalah nabi Muhammad saw. sebagai penerima pesan dari Tuhan dan para sahabat karena mereka orang yang dituju oleh teks-teks itu dan berinteraksi langsung dengan teks tersebut. $^{23}$

Lebih lanjut dijelaskan bahwa tehnik tafsir bi al-ma'thür adalah menafsirkan teks al-Qur'ān dengan al-Qur'ān. Jika tidak ditemukan dalam alQur'ān maka penafsiran menjarah pada wilayah kekuasaan hadits. Tafsir teks al-Qur'ān dengan al-hadits adalah alternatif kedua (the second resource) mengingat hadits berfungsi untuk menjelaskan keburaman makna al-Qur'ān. Dan bila dalam sunah tidak dijelaskan maka merujuk kepada apa yang diriwayatkan oleh para sahabat karena mereka adalah paling tahu mengenai alQur'ān. Terakhir, jika dalam fatwa sahabat tidak ditemukan, maka ambilah fatwa-fatwa para senior dari tabi $\bar{i}$ in, karena mereka adalah orang-orang yang berinteraksi langsung dengan para sahabat. Ini menunjukkan bahwa penafsiran dengan bentuk tafsir bi al-ma'thür adalah sebuah kerja penafsiran yang bertumpu pada landasan periwayatan. Penafsir tidak diperkenankan menafsirkan teks al-Qur'ān tanpa mendasarkan pada periwayatan yang tentu harus terjamin keakuratannya. ${ }^{24}$

${ }^{23}$ Lihat Muhammad Ḥamd Zaghlūl, al-Tafsì̄ bi al-Ra'y: Qawā'iduh, Dawābițuh, wa 'Alämuh (Dimashq: Maktabah al-Farabi, 1999), 105. Bandingkan dengan Ibn Taimiyah, Muqaddimah fì Ușūl al-Tafsìr, ed. 'Adnān Zarzūr (Kuwait: Dār al-Qur'ān, 1971/1391), 93- 105.

${ }^{24}$ Mannā' al-Qațān, Mabāhith fi 'Ulūm al-Qur'ān (Riyad: Maktabah Dār alHadīth, 1973), 347. Lihat Ṭāhir Maḥmūd Muḥammad Ya'qūb, Asbāb al-Khata' fì alTafsìi, Juz I, (Riyaḍ: Dār Ibn Jauziyah, 1425 H), 55. Menarik menyimak perkataan Imām 
Ibn Taimiyah menyatakan bahwa nabi Muhammad Saw menjelaskan tentang makna-makna al-Qur'ān kepada para sahabatnya sebagaimana beliau menyampaikan alfaz-nya. Pandangan ini didasarkan pada dua argumen. Pertama sabdanya Allah dalam QS. al-Nahl (16):44 menjelaskan bahwa Nabi berkewajiban untuk memberikan penjelasan pada manusia tentang apa yang termaktub dalam al-Qur'ān. Ini mengilustrasikan bahwa Nabi telah menjelaskan tentang makna-makna yang dikandung oleh al-Qur'ān.

Kedua mengacu pada perkataan Abd al-Raḥmān al-Sālimī (w.76 H)," kami terima al-Qur'ān ini dari para sahabat yang membacakannya kepada kami seperti Uthmān ibn 'Affān (644-655 M), Abdullāh ibn Mas'ūd dan lainnya. Mereka tidak akan menambah pelajaran al-Qur'ān sebelum pelajaran sebelumnya telah dihafal, dimengerti dan diamalkannya semuanya". ini diperkuat oleh Mālik ibn Anas bahwa sahabat Anas ibn Mālik menghafalkan (baca: tadabbur) surat al-Baqarah selama delapan tahun. Ini sangat dimungkinkan mengingat al-Qur'ān memerintahkan untuk tadabbur sebagaimana terekam dalam QS. al-Nisā (4):81 dan QS. Shād (38):29 dan langkah menuju ke sana adalah dengan mengetahui makna teks al-Qur'ān ${ }^{26}$.

Jika mengacu pada teori hermeneutika Schleiermacher yang menyatakan bahwa kerja interpretasi teks adalah merupakan pekerjaan reproduktif, maka ada aturan main (the role of game) yang harus diperankan dan diaplikasikan oleh seorang penafsir. Aturan pertama, penafsir harus mengenal ayat-ayat yang akan ditafsirkan (al-mufassar bih) dan mengenal ayat-ayat al-Qur'an yang akan dijadikan media penafsiran (al-mufassar 'alaih).

Pengenalan yang dimaksud adalah 1) mengetahui tentang bahasa Arab dan aspek-aspeknya. Ini prasyarat utama, mengingat mustahil seorang penafsir mampu menafsirkan satu teks jika tidak mengenal dan menguasai bahasa yang dijadikan medium tersebut. Apalagi al-Qur'an dengan bahasa Arabnya adalah sebuah tutur bahasa arab (lisān arabi) yang mempunyai keunggulan dan

al-Shāfi ‘⿳亠丷厂: segenap hukum yang disampaikan oleh nabi Muhamad saw adalah berasal dari al-Qur'ān". Lebih lanjut lihat Muqaddimah fì Ușūl al-Tafsìir, ed. 'Adnān Zarzūr (Kuwait: Dār al-Qur'ān, 1971/1391), 93. Imam Ahmad ibn Hanbal berkata bahwa salah satu fungsi sunah adalah menafsirkan dan menjelaskan al-Qur'ān. Lihat Abū Abdillāh Muhammad al-Qurțūbì, Al-Jāmi ' li Ahkām al-Qur'ān, Juz I, (Beirut: Dār Ihỵā, 1967), 39. ${ }^{25}$ Mannā' al-Qattān, Mabāhith fī 'Ulüm al-Qur'ān (Riyad: Maktabah Dār alHadith,1973), 348. Lihat juga al-Suyūtị, Al-Itqān fì 'Ulūm al-Qur'ān, Juz IV, ed. Muhammad Abū al-Faḍl Ibrāhim (Kairo: Madhhab Husaini, tt), 174. Lihat Badr al-Dīn al-Zarkashī, Al-Burhān fì 'Ulūm al- Qur'ān, Juz 2 (Kairo: 'Īsā al Halabīi, 1374 H), 175. Lihat juga Muhammad Muhammad al-Mahdī, Al-Wāhidi wa Manhajuh fī al-Tafsìr (Kairo: Jumhuriyah Mișr al-“Arabiygyah Wizārat al-Auqāf, tt), 99. Bandingkan dengan Muhammad Ḥamd Zaghlūl, al-Tafsir bi al-Ra'y, 432.

${ }^{26}$ Al-Suyūțì, Al-Itqān fì̀ 'Ulūm al-Qur'àn, Juz II, 176. 
keunikan tersendiri. ${ }^{27}$ Dalam hal ini, Imam Mujāhid (w 103H/721M) memberikan warning yang cukup keras. Menurutnya sangat tidak layak bagi seseorang yang mengaku beriman kepada Allah dan Hari Akhir berbicara menafsirkan -- al-Qur'an tanpa dibekali oleh kemampuan penguasaan bahasa Arab yang komprehensif dan mampuni. ${ }^{28}$

Penguasaan bahasa Arab berarti menguasai ilmu nahwu (grammatical Arabic), ilmu sorof (morfologi) dan sastra (baläghah). ${ }^{29}$ Satu teks akan menuai dan membuai beberapa makna dengan perbedaan $i^{\prime} \mathrm{rab}$ (perubahan akhir kata). Di sinilah ilmu nahwu menemukan sarangnya. Dan karena perbedaan bentuk kata maka lahirlah beberapa makna dari asal satu kata, dan inilah proyek ilmu sorof. Ia bermain dalam wilayah perubahan bentuk kata yang akhirnya terbuailah variasi makna. Untuk mengetahui sejauh mana teks itu memberikan kejelasan makna, diperlukan ilmu balaghah sebagai alat mengukur kejelasan (alwuḍūh) dan kesamaran (al-khafá') makna yang ditunjukkan oleh teks tersebut. ${ }^{30}$

Aturan kedua adalah mengetahui ilmu-ilmu pokok yang berkaitan dengan al-Qur'ān (al-'ulūm al-uṣūliyyah al-muttașilah bi al-Qur'ān). Ilmu ini dikenal dengan istilah 'ulūm al-Qur'ān seperti ilmu qiră'at, tauhid, ilmu ushul dan ilmuilmu yang dibutuhkan dalam penafsiran seperti mengenai asbāb al-nuzūl, nāsikh mansūkh dan sebagainya. Asbāb al-nuzūl adalah penyebab, faktor dan latar belakang diturunkannya sebuah ayat. Pengetahuan terhadap bidang ini sangat urgen mengingat asbāb al-nuzūl berbicara tentang kondisi sosial psikologis dan historis dari ayat tersebut. Asbāb al-nuzūl kadangkala merupakan respon dan reaksi terhadap kondisi real masyarakat, baik dalam bentuk verbal atau non verbal. Ia juga bisa merupakan sebuah pertanyaan yang diajukan kepada Nabi untuk menyingkap hukum atau makna yang dikehendaki oleh Allah SWT.

${ }^{27}$ Tăhā Husain berpandangan bahwa teks al-Qur'an sebagai dokumen sastra suci. Sikap Ṭăhā Husain yang demikian ini menjadi indikator pemberlakuan teks al-Qur'an sebagai tafsir sastra Arab terbesar. Lihat M. Nur Khalis Setiawan, al-Qur'an Kitab Sastra Terbesar (Yogyakarta: eLsAq Press, 2005), 28.

${ }^{28}$ Mannā' al-Qatțān, Mabāhith fì 'Ulūm al-Qur'ān, 331.

${ }^{29}$ Salah satu kajian dalam ilmu balaghah adalah majāz (metaforis) yaitu pemaknaan yang disingkap tidak secara zāhiriyyah. Berkaitan dengan majaz, ada tiga aliran yang kontradiktif dan akomodatif. Pertama Mu'tazilah yang menjadikan majaz sebagai senjata untuk memberikan interpretasi terhadap teks-teks al-Qur'ān. Kedua, Zāhiriyyah yang menempatkan secara keras dan tegas menolak pemahaman apapun terhadap teks yang melampui lahiriyah bahasa. Ketiga Ash'ariyah yang mencoba mengakomodasi kedua kubu yang sedang bersitegang itu. Kelompok ketiga ini berpendapat bahwa majaz bisa digunakan dalam penafsiran teks al-Qur'an selama tidak berlebihan. Lihat Abū Zayd, Hermeneutika Inklusif, 172.

${ }^{3_{0}}$ Mannā' al-Qațtān, Mabāhith fí 'Ulūm al-Qur'ān, 331. Lihat juga al-Ahḍari, Jawāhir al-Maknūn dalam Majmū‘ al-Mutūn (Probolinggo: Penerbit PP. Nurul Qadim), 16. 
Aturan ketiga adalah berhubungan dengan integritas dan kredebilitas kepribadian penafsir. Dalam diri internal penafsir harus tertanam kuat niat baik, terpateri akhlak yang baik, aplikatif, rendah hati dan tidak sombong. Berani bersuara benar walau terasa pahit, pandai dalam beretorika, dan punya malakah dalam hal penafsiran ${ }^{31}$.

Dalam hal otentisitas tafsir bi al-ma'thür, Ignaz Goldziher (1850-1921 $M)^{32}$ memberikan penilaian bahwa hampir seluruh himpunan hadits yang memuat dan tersusun menurut materinya pasti memuat bab tafsir al-Qur'an, yaitu sekumpulan berita yang memuat tentang penafsiran nabi terhadap alQur'an. Sumber-sumber yang tertulis dalam riwayat Islam sangat luar biasa karena nyaris saja sumber-sumber itu tidak meninggalkan kebingungan dalam menyelesaikan persoalan. Goldziher mencontohkan seorang sarjana muslim produktif yaitu Jalāluddīn al-Suyūți (w.911H./1505M). Al-Suyūți mampu menyusun dan merangkum kurang lebih dari sepuluh ribu hadits dari penafsiran nabi Muhammad dan sahabat-sahabatnya yang terangkum dalam enam jilid (alDurr al-Manthür fi al-Tafsir bi al-Ma'thür $)^{3 \mathbf{3}}$.

Tokoh utama yang dijadikan rujukan dalam tafsir bi al-ma'thür dari kalangan sahabat adalah Abū Bakar (51 Sebelum H.-13 H/573-634 M), 'Umar ibn Khațtab (41 SH-24 H/582-645), 'Uthmān ibn 'Affān (47 SH-35 H/577-655

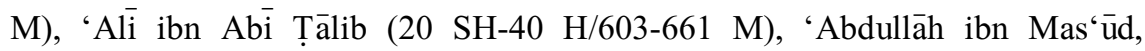
'Abdullāh ibn 'Umar, 'Abdullāh ibn 'Umar ibn 'Āṣ, Abū Mūsā al-Ash'arī, Zaid ibn Thābit, Ubay ibn Ka'ab, 'Āishah bint Abū Bakar. Sedangkan dari kalangan tabi‘īn yang masyhur adalah Mujāhid ibn Jabbār (w 103H/721M), Sa‘īd ibn Jābir (w. 95 H), Qatādah ibn Du'āmah al-Sadūsì (w. 117), Zaid ibn Aslam, Muhammad ibn Ka'b al-Qirādhī, Abū al-'Āliyah al-Rayyah (w. 90 H), 'Ațā' ibn Abì Rabbāh, 'Ikrīmah Maulā ibn 'Abbās (w.105/724 M), Hasan al-Bașrì (w. 121 $\mathrm{H}), \mathrm{Sa}{ }^{\overline{\mathrm{i}} \mathrm{d}}$ al-Musayyab, dan masih banyak lagi yang lainnya. ${ }^{34}$

${ }^{31}$ Mannā' al-Qațtān, Mabāhith fi 'Ulūm al-Qur'ān, 334.

32 Ignaz Goldziher adalah orientalis berdarah Yahudi, memperoleh gelar doktoralnya-dengan topik Penafsir Taurat yang Berasal dari Tokoh Yahudi Abad Tengah" di bawah asuhan Flieser. Ada dua karya monumental yang dihasilkan oleh Goldziher yaitu Muḥạuarät fì al-Islām (Heidelberg, 1910) dan Ittijāhät Tafsìr al-Qur'ān 'inda al-Muslimin (Lieden, 1920). Secara umum, buku pertama berbicara Islam ditinjau dari berbagai aspeknya sedangkan buku yang kedua mendiskusikan dan mengulas tentang penafsiran dan ilmu tafsir. Ia telah banyak berkecimpung dalam kajian keislaman dan telah dijadikan bahan rujukan oleh umat Islam. 'Abd al-Raḥmān Badawi, Mausu' 'àt al-Mustashriqīn, terj. Amroeni Derajat, Ensiklopedi Tokoh Orientalis (Yogyakarta: LkiS, 2003), 143-145.

${ }^{33}$ Ignaz Goldziher, Madhāhib al-Tafsìir al Islāmī (Beirut: Dār al Iqra', 1983), 89.

${ }^{34}$ Fahd ibn 'Abd al-Raḥmān, Ușūl al-Tafsìr wa Manāhijuh (Riyạ̣̄: alTaubah,1413H), 86. Lihat juga Mannā' al-Qaț̣ān, Mabāhith fì 'Ulūm al-Qur'àn, 339. Lihat juga Abdul Mustaqim, Aliran-Aliran Tafsir, 53. 
Sekedar penambah memori, dari sekian mufassirin bi al-ma'thür yang mempunyai penilaian istimewa dalam hati kaum muslimin adalah Ibn 'Abbās, putra paman Rasulullah Saw. Ia adalah icon penafsir bi al-ma'thür dan merupakan mukjizat tafsir dan lautan ilmu serta tinta umat ini. Ia juga menyandang gelar turjumān al-Qur'ān yang telah diberkahi oleh Rasulullah

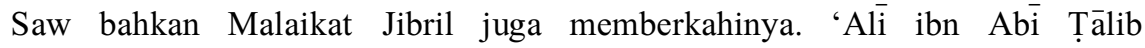
menyebutnya sebagai orang yang kuat dalam hal pemahaman. Informasi tafsir yang disanadkan kepadanya akan sangat berpengaruh dalam kehidupan kaum muslimin. Mujāhid (w 103H/721M) (55 $^{35}$ murid Ibn 'Abbās berkomentar "ketika Ibn Abbas menafsrikan ayat al-Qur'an maka aku melihat seberkas cahaya dari wajahnya,

Tidak berlebihan bila Ibn Taymiyah $(661-728 \mathrm{H})$ menyatakan bahwa perbedaan di antara kaum salaf mengenai penafsiran al-Qur'an bi al-ma'th $\bar{u}$ jarang ditemui, kalaupun ada itu tidak lebih perbedaan dalam variasi makna yang bertumpu pada satu poros, bukan perbedaan yang bertentangan. Ia mengemukakan tamsil yaitu kata al-ṣirät al-mustaqïm. Sebagian kalangan ulama menafsirkan al-sirät al-mustaqīm adalah al-Qur'an dan sebagian yang lain menafsirkannya sebagai agama Islam. Perbedaan penafsiran semacam ini bukanlah penafsiran yang saling bertentangan (al-ittị̂ād) akan tetapi satu kesepahaman karena al-Qur'an dan agama Islam adalah talāzum yaitu keberadaan al-Qur'an dalam agama Islam adalah satu kesatuan seperti anak dan orang tua. $^{37}$

Bisa disimpulkan bahwa upaya menyeberang (accross) ke lautan masa lalu untuk menemukan makna yang akurat merupakan sebuah keniscayaan dalam bangunan penafsiran. Akan tetapi teori ini bukan berarti tidak meyimpan cacat yang bersemayam dalam badan tafsir bi al-ma'thür. Cacat itu adalah masalah keotentikan riwayat yang dijadikan landasan atau hujjah dalam penafsiran itu. Permasalahan kedua adalah bahwa zaman yang dihadapi para

${ }^{35}$ Era Mujāhid ibn al-Jabbār disinyalir merupakan pangkal dari perkembangan teorisasi bahasa yang erat kaitannya dengan interpretasi al-Qur'ān. Mujahid dengan beberapa sarjana al-Qur'ān semasanya memberikan interpretasi ayat-ayat al-Qur'ān yang dijadikan pijakan penafsiran metaforis terhadap al-Qur'ān. Salah satu contohnya adalah penafsiran terhadap surah al-Baqarah (2): 65. Frase"jadilah engkau kera yang hina", Mujāhid tidak menafsirkan secara fisik bahwa mereka berubah menjadi kera, namun perubahan itu hanya perilakunya. Hal ini disebabkan kalimat tersebut merupakan pemisalan. Lihat. Mujāhid ibn Jabbār, Tafsir Mujāhid, (Islamabad, tt.), vol. I, 77-778. Lihat juga M. Nur Kholis Setiawan, “Al-Qur'ān dalam Kesarjanaan Klasik dan Kontemporer," dalam Journal Studi al-Qur'ān, Vol I, No 1, Januari 2006.

3ิ Ignaz Goldziher, Madhāhib al-Tafsìir al Islāmì, terj. 'Abd al-Ḥalim al-Najjār (Beirut: Dār Iqra’,1983), 89. Juz II, 177.

${ }^{37}$ Mannā' al-Qaț̣̄ān, Mabāhith fi 'Ulūm al-Qur'ān, 348. Lihat al-Suyūṭi, al-Itqān, 
pendahulu jauh berbeda dengan zaman penafsir sekarang. Jika berkutat pada tafsir bi al-ma'thūr, mampukah al Quran memberikan jawaban solutif? Kalau orang berkeyakinan bahwa tafsir bi al-ma'thür sebagai satu-satunya tafsir yang benar, maka pertanyaan yang muncul adalah apa makna al-Qur'an bagi penafsir untuk saat ini? Kalau memang al-Qur'an berbicara untuk semua orang, untuk semua zaman dan tempat, maka manusia saat inipun berhak untuk menafsirkan al-Qur'an sesuai dengan keadaan, kemampuan bicara, menalar dan kebutuhan aktual lainnya.

Tawaran yang disodorkan adalah bentuk penafsiran yang kedua yaitu tafsir bi al-ra'y yaitu pandangan bahwa teks dapat dimengerti oleh orang-orang yang tidak semasa dengan ketika teks itu dilahirkan dan berada di luar tradisi pengarangnya. Pendekatan ini lebih menitikberatkan pada gramatikal-tekstual. ${ }^{38}$ Argumentasi yang digunakan adalah bahwa teks al-Qur'ān adalah sebuah teks yang telah sempurna dan bisa dipahami oleh siapa saja yang mempunyai kompetensi memahaminya. Lebih jauh lagi bahwa al-Qur'an diyakini mempunyai kemukjizatan bahasa yang luar biasa sehingga penguasaan bahasa Arab secara benar sudah cukup dalam memahami teks-teks al-Qur'ān. Pendekatan ini banyak menonjol dalam kajian ilmu fiqh, kalam dan mistik (tasawwuf). ${ }^{39}$

Rekaman tafsir bi al-ra'y bisa dilihat dalam ilmu Fiqh seperti perbedaan polemik tertib dalam pelaksanaan ritual wudu'. Imām Abū Hanifah (80-150 H/700-767 M. $)^{40}$ sama sekali tidak mensyaratkan tertib dalam pelaksanaan

${ }^{39}$ Penafsiran dengan model ini sudah muncul sejak zaman sahabat semisal Ibn 'Abbās (w. $68 \mathrm{H}$ ) yang menafsirkan dengan merujuk pada syair syair Arab dalam menafsirkan ayat al-Qur'ān yang asing dalam pandangan mereka. Dalam satu riwayat, 'Umar baru menerima penafsiran takhawwuf setelah menerima penjelasan tentang makna kata tersebut yang dirujuk pada syair Arab. ${ }^{3 \%}$ Dalam rentetan tafsir klasik, corak penafsiran ini bisa direkam dalam tafsir Jāmi' al-Bayān 'an Ta'wì $\bar{A} \bar{y}$ al-Qur'ān, karya al-Ṭabari (w. 310 H). Semisal dalam menafsirkan sūrah al-Fātiḥah, al-Ṭabari sering merujuk pada aspek-aspek kebahasaan, terutama syair-syair Arab untuk menemukan makna kandungan ayat dalam sūrah al-Fātihah tersebut. Lihat Muhammad Husain alDhahabìi,al-Tafsiri wa al-Mufassirūn, Jilid I (Kairo: Dār al-Kutub al-Ḥadithah,1961), 74. Lihat juga Al-Fatih Suryadilaga dkk, Metodologi Ilmu Tafsir (Yogyakarta: Teras, 2005), 86. Lihat al-Ṭabarì, Jāmi' al-Bayān 'an Ta'wì Ây al-Qur'ān, Juz I, (Beirut: Dār al-Fikr, tt), 85-87.

${ }^{39}$ Machasin, "Sumbangan Hermeneutika terhadap Ilmu Tafsir," 123 dan Hidayat, Memahami Bahasa Agama, Sebuah Kajian Hermeneutik (Jakarta: Paramadina, 1996), 149.

40 Imam Abū Hanifah dalam melahirkan hukum banyak dipengaruhi oleh perkembangan hukum yang terjadi di Kufah. Sebagai kota metropolis dan jauh dari Madinah, tentunya problematika kehidupannya lebih komplek dan berkembang dari Madinah, dan sirkulasi hadits atau sunah lebih sedikit dibandingkan Madinah. Menarik untuk dicermati mengenai perkataan Abū Hanifah:" Pertama-tama saya mencari dasar hukum dari al-Qur'ān, lalu dari sunah jika al-Qur'ān tidak menjelaskannya, kalau tidak 
ritual wudu', sementara imām Shāfi'ì (150-204 H/767-819 M), Ahmmad ibn Hanbal (780-855 M) dan Abū'Abīd berpendapat bahwa tertib merupakan salah satu rukun wudu' yang harus dikerjakan. Perbedaan ini berangkat dari sudut pandang mereka dalam memotret QS. Al-Mā'idah (5): 5). Abū Ḥanifah, Mālik ibn Anas (93-179/712-795 M), al-Thaurì dan Daud al-Ẓāhiri tidak meleburkan tertib sebagai bagian fard $w u d \underline{u}$ '. Pandangan ini didasarkan pada pendapatnya ulama Bașrah yang berpendapat bahwa waw dalam ayat tersebut tidak memberikan makna runtut akan tetapi hanya sebatas huruf penyambung belaka dan mengisyaratkan bahwa semua lafal-lafal yang diatafkan dengan menggunakan waw itu adalah termasuk bagian dalam fard wuḍu, , namun tidak mengandung makna sistematis. ${ }^{41}$

Pandangan ini berbeda dengan imām Shāfi ‘⿳亠丷, Aḥmad ibn Ḥanbal (780$855 \mathrm{M})$ dan $\mathrm{Abu}$ 'Abìd yang mengkatagorikan tertib sebagai bagian dari fard wudū'. Pendapat ini terinspirasi oleh pendapat ulama Kufah yang meletakan WaW sebagai organ dari huruf 'ataf yang menyuplai makna tertib ${ }^{42}$.

Faktor yang kedua dipicu oleh cara pandang mereka dalam menafsirkan sunah nabi Muhammad Saw tentang tata cara pelaksanaan wudu'. Imam alShäfi' $\bar{i}$ berpandangan bahwa tata cara berwudu' yang dilakukan oleh nabi adalah hal yang wajib untuk diikuti selama belum ada penjelasan yang membatalkan (al-bayyinah al-munqati'ah) tentang keakuratan atau ke-fardu-an sunah itu. Sebaliknya, Abū Hanifah berpendirian bahwa tata cara berwudu' yang dilaksanakan oleh nabi Muhammad tidak selamanya sesuatu yang wajib untuk diikuti. Salah satu contohnya adalah masalah tertib. ${ }^{43}$

Permasalahan pelaku dosa besar memunculkan polemik yang sangat rumit dan meruncing sehingga melahirkan perpecahan serta pertumpahan darah. Lagi-lagi, salah satu faktornya adalah perbedaan sudut pandang dalam meneropong teks-teks suci al-Qur'ān yang memicu terhadap munculnya kelompok Khawarij, ${ }^{44}$ paham Jabariyah dan Qadariyah. Khawarij menilai

ada, saya memilih fatwa para sahabat yang paling kuat.....selanjuntnya jika orang berijtihad, maka akupun melakukannya”. Inilah yang digunakan oleh Abū Hianifah dalam proyek penggalian hukum Islam. Tak ayal dia kemudian terkenal dengan madhhab ahl alra'y (golongan rasionalis). Harun Nasution, Islam Ditinjau dari Berbagai Aspeknya, Jilid II (Depok:UI Press, 2002), 8.

${ }^{41}$ Ibn Rushd, Bidāyat al-Mujtahid, Juz I (Kairo: Maktabah Kulliyah alAzhar,1969), 11.

${ }^{42}$ 'Abd al-Rahmmān Al-Jazìiri, al-Fiqh 'alā al-Madhāhib al-Arba'ah, Jilid I (Beirut: Dār al-Fikr, tt), 51 .

${ }_{4}^{43}$ Ibn Rushd, Bidāyat al-Mujtahid, Juz I, 12.

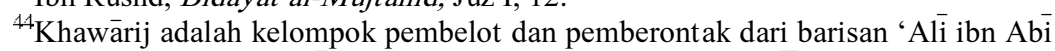
Ṭālib. Mereka memandang 'Ali dan Mu'āwiyah serta 'Umar ibn 'Ās telah kafir karena telah mencampuradukan kebenaran (al-haqq) dan kepalsuan (al-bătil) dan memutuskan untuk membunuh ketiganya. Karena sikap mereka yang sangat ekstrem dan 


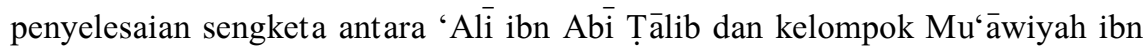
Ṣafyān (w.680 M) bukanlah penyelesaian yang dituntun oleh al-Qur'ān, oleh karenanya pihak-pihak yang terkait dalam arbitrase adalah kāfir yaitu lawannya mukmin, keluar dari Islam, alias murtadd. Dalam al-Qur'ān kata al-mu'min dan al-käfir selalu diposisikan dalam posisi berseberangan. Kafir adalah orang yang tidak percaya kepada Nabi Muhammad dan ajaran beliau akan tetapi kelompok khawarij menggunakan term kafir untuk kalangan muslim yang tidak menjalankan hukum Allah. Pemahaman kelompok ini didasarkan pada QS.alMāidah (4): 44 yang menyatakan, "Siapa yang tidak menentukan hukum dengan apa yang telah diturunkan ialah kafir" "45.

Pendekatan lain dalam memahami teks al-Qur'ān adalah mistikal filosofis yang lebih mendahulukan makna batiniyah daripada makna leterlek dari suatu proposisi yang terdapat dalam teks al-Qur'ān. Proposisi dari teks alQur'ān itu hanyalah sebagai media atau pintu masuk untuk menemukan makna atau pengertian di luar makna luar yang bersifat proporsional. Pendekatan filsofis ini tanpa diikuti penghayatan mistis sering dianggap berbahaya karena pendekatan filosofis ini murni penalaran logis. Ibarat Qais al-majnūn, setiap langkahnya adalah sebuah pengembaraan yang tidak pernah berakhir untuk menemukan kekasih hatinya, Laila, yang selalu dirindukan. ${ }^{4 / 6}$

Icon atau guru besar dari penafsiran mistikal filosofis itu adalah seorang

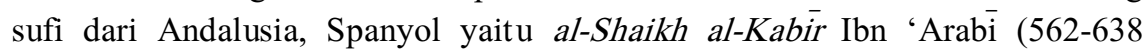
H/1065-1124M). Secara umum, dia adalah sosok utama yang paling populer dalam ranah tasawuf. Dia misalnya menafsirkan QS. al-Qaṣaṣ: 7 dan selanjutnya tentang kisah penghanyutan nabi Mūsā as ke sungai Nil. Dia menemukan beberapa isyarat dalam kisah tersebut yaitu bahwa kotak yang di dalamnya berisi Mūsā bermakna karakter kemanusiannya dengan daya inderawi dan daya pemikirannya.

Sementara sungai di mana Mūsā dihanyutkan bermakna ilmu dan pengetahuan yang sangat tinggi. Dan sesungguhnya Mūsā mampu sebagaimana manusia lainnya untuk menembus yang kedua dengan perantaraan yaitu karakter, daya inderawi, dan daya pengetahuan. Demikian juga ibu yang

eksklusifistik, kaum Khawarij akhirnya boleh dikatakan punah walau sebenarnya, akhirakhir ini, pola pemikiran dan pengaruhnya masih sangat kental dan mengakar kuat. Ini bisa dilihat dari peristiwa-peristiwa yang mulai mengancam keramahan Islam. Nurcholish Madjid, Islam Doktrin dan Peradaban (Jakarta: Paramadina, 2000), 206.

${ }^{45}$ Untuk lebih detail lihat Harun Nasution, Islam Ditinjau dari Berbagai Aspeknya, Jilid II (Depok:UI Press, 2002), 26.

${ }_{46}$ Ignaz Goldziher, Madhāhib al-Tafsìi al-Islāmì, 202. Bandingkan dengan Țāhir Maḥmūd Muhammad Ya‘qūb, Asbāb al-Khata' fì al-Tafsìr, Juz I, 768 dan Tim Penulis Pusat Studi Al-Qur'ān, Kekerasan Atas Nama Agama (Jakarta: Lentera Hati, 2009), 9. Lihat juga Muhsin 'Abd al-Ḥamìd, Haqūiat al-Bābiyah wa al-Baha'iyah (Kairo: Dār alȘahwah, 1985), 22. 
menyusui mempunyai peran dalam takwil imajinatif ini. Kemudian Mūsā menolak untuk menerima susuan dari siapa saja selain ibunya sendiri. Ini mengisyaratkan bahwa Mūsā akan mengganti syariat-syariat orang-orang terdahulu karena dia adalah rasul. ${ }^{47}$

Begitulah, kisah perjalanan al-Qur'ān, selama kurang dari empat belas (14) abad, al-Qur'ān menemui majelis para pembacanya, berjumpa dengan berbagai ragam metode, sikap dan kapasitas intelektualitas yang sangat varian sehingga kesan dan pemahaman terhadap teks al-Qur'an juga bervarian dan beragam. Ada sebagian umat Islam yang mengharuskan untuk mengetahui asbāb al-nuzūl untuk mengetahui kondisi psikologi historis teks al-Qur'ān sehingga pemahaman dan penafsiran terhadap teks al-Qur'an bisa komprehensif. Ada pula yang meyakini bahwa teks al-Qur'ān adalah rekaman kalämullāh yang abadi dan universal, maka sebagian umat Islam merasa tidak perlu untuk melirik asbāb al-nuzul dan historis turunnya ayat. Pandangan ini menyatakan bahwa penafsiran yang mengacu pada asbāb al-nuzul dan kondisi psikologis di mana ayat diturunkan hanya akan mengurangi makna universalitas dari ayat itu tersendiri. ${ }^{48}$

Sebenarnya, al-ra'y (rasio) digunakan sebagai media berfikir dalam menafsirkan al-Qur'an sudah mulai terdeteksi sejak masa sahabat. Diceritakan bahwa para sahabat jika tidak menemukan ayat dalam al-Qur'an dan tidak menemukan pula dalam sunah Rasulullah saw. maka mereka berijtihad bi al-ra'y dalam menafsirkan al-Qur'an. Tentu, akurasi produk penafsiran mereka terjamin, mengingat mereka adalah pribumi Arab, mengerti bahasa dan keindahan bahasa dengan baik dan teruji. Hasil ijtihad mereka inilah kemudian yang dijadikan acuan dan pedoman sehingga kemudian produk mereka yang awalnya bi al-ra'yi berubah menjelma menjadibi al-ma'thur untuk generasi

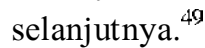

Kata al-ra'y dalam sejarahnya sangat kental dengan peristiwa dialog sahabat Mu'adh bin Jabal dengan Rasulullah saw ketika ia hendak berangkat ke Yaman sebagai Gubernur. Ketika Nabi bertanya tentang bagaimana ia akan menghukumi suatu permasalahan yang timbul, ia menjawab bahwa dia akan berkiblat kepada al-Qur'an, bila tidak ditemukan jawabannya dalam al-Qur'an

${ }^{47}$ Ibn 'Arabī, Fușuṣ al-Hikam, Hakikat Kedua Puluh Lima, Jilid II (Beirut : Dār al-Fikri, tt), 269-281. Lihat juga Goldziher, Madhāhib al-Tafsìr al-Islāmīi, 273.

${ }^{48}$ Hidayat, Memahami Bahasa Agama, Sebuah Kajian Hermeneutik, 151. Lihat al-Zarkashī, al-Burhān fì 'Ulūm al-Qur'ān, Juz I, 45-51. Bandingkan dengan Shahrūr, Naḥw al-Ușūl al-Jadidah Li Fiqh al-Islam (Damaskus: al-Ahali, 2000), 15 dan 230, dan Shahrūur, al-Kitāb wa al-Qur'ān: Qirā'ah Mu'āṣirah (Damaskus: al-Ahali, 1992), 92.

${ }^{49}$ Mannā' al-Qațāan, Mabāhith fì 'Ulūm al-Qur'ān, 348. Lihat juga Ibn Taimiyah, Muqaddimah fì Ușūl al-Tafsir, 108. 
maka ia akan merujuk pada sunah rasul-Nya. Dan jika ternyata dalam sunah Rasul-Nya tidak termaktub, maka ia akan berijtihad dengan ra'y.

Ini menandakan bahwa penggunaan nalar (rasio) dalam tradisi Islam sama sekali tidak dilarang bahkan banyak ayat-ayat al-Qur'an yang menganjurkan untuk tadabbur untuk memahami ayat al-Qur'an baik yang verbal atau non verbal. Penggunaan nalar dalam menafsirkan al-Qur'an bisa ditolerir selama bisa dipertanggung jawabkan secara ilmiah dan memenuhi kretaria yang telah ditetapkan oleh para mufassir. Menafsirkan al-Qur'an hanya berdasarkan rasio belaka dan tanpa ada patokan metodologis yang bisa dipertanggung jawabkan tentu tidak dibenarkan, selain hasilnya akan serampangan dan tidak bisa dipertanggung jawabkan, juga hanya akan menimbulkan kerancuan. ${ }^{50}$

Pembatasan ini didasarkan pada firman Tuhan (QS. al-Isrā’: 36). Di sana dikatakan, “dan janganlah kamu mengikuti apa yang kamu tidak mempunyai pengetahuan tentangnya. Sesungguhnya pendengaran, penglihatan dan hati, semuanya itu akan diminta pertanggungan jawabnya”. Dan juga mengacu pada hadits Nabi," barang siapa yang berkata mengenai al-Qur'an dengan ra'yunya atau pendapat yang tidak diketahui akurasinya, maka tempatnya adalah neraka". Bahkan dalam teks lain dikatakan,"siapa yang berkata (menafsirkan) al-Qur'an dan benar maka ia masih keliru" "5I

Ibn Taimiyah (661-728 H) menyatakan bahwa siapa saja yang berpindah dari madzhab sahabat atau tabi'in (tafsir bi al-ma'thür), beralih kepada tafsir bi al-ra'y padahal penafsiran dan penjelasannya sudah ma'thur, maka ia termasuk orang yang keliru dan telah berbuat bid'ah. Alasan yang dikemukan oleh Ibn Taimiyah adalah para sahabat dan tabi'in adalah yang paling mengerti mengenai makna-makna yang terkandung dalam ayat tersebut. ${ }^{52}$

Tafsir bi al-ra'y bisa dihubungkan dengan teori hermeneutika HansGeorg Gadamer (1900-2002) yang menyatakan bahwa tugas hermeneutika tidak hanya menemukan makna, tetapi suatu interpretasi terhadap teks tetap terbuka dan tidak terbatas pada maksud si pengarang, karenanya kegiatan interpretasi

${ }^{50}$ Lihat Ibn Taimiyah, Muqaddimah fî̀ Ușūl al-Tafsìi, 105. Lihat juga Abdullah Saeed, Interpreting the Qur'an: Towards a Contemporary Approach (Oxford: Routledge, 2006), 61. Dan lihat Muhammad Husain al-Dhahabi, al-Tafsir wa al-Mufassirūn, Juz I (Beirut: Dār al-Kutub, 1409 H), 153.

${ }^{51}$ Hadith ini diriwayatkan oleh al-Turmudhì, al-Nasā', $\bar{i}$, Abū Daud. Al-Turmudhì menyatakan bahwa hadith ini hasan. Lihat juga Muhammad Hamd Zaghlūl, al-Tafsis bi al-Ra'y, 106. Lihat juga Ahmad Thib Raya, Rasionalitas Bahasa al-Qur'ān: Upaya Menafsirkan al-Qur'ān dengan Pendekatan Bahasa (Jakarta: Fikra, 2006), 4. Lebih jauh Mannā' al-Qattān menuduh bahwa tafsir seperti al-Kashshäf karya al-Zamakhsharī, Abd al-Jabbār, al-Jubbā', $\bar{i}$, al-Rummāni adalah tafsir dan mufassir ahli bidah, karena mereka telah menyalahi kaidah-kaidah ahl al-salaf (sahabat dan tabi‘̄in). Mannā‘ al-Qatțān, Mabāhith fì 'Ulüm al-Qur'ān, 353.

${ }^{\bar{s} \mathrm{M} M a n n a ̄ '}$ al-Qațtān, Mabāhith fì 'Ulūm al-Qur'ān, 353. 
bukan hanya reproduktif belaka tapi juga produktif. Lebih lanjut ia mengatakan sekali teks dilempar ke permukaan dan ruang publik, ia telah hidup dengan nafasnya sendiri. Tidak ada kaki referensi yang menopangnya bahkan oleh penggagasnya sekalipun (the death of the author). Dalam pandangan Gadamer, hermeneutika tidak lagi bertugas untuk menemukan makna yang dituju oleh pengarangnya akan tetapi memproduksi makna yang seluruhnya memusat pada kondisi historis dan sosial pembaca ${ }^{53}$

Harus diakui bahwa konsep pemikiran di atas sangat merisaukan kalangan agamawan atas keberlangsungan teks-teks suci mereka, termasuk teks suci al-Qur'ān. Teori hermeneutika Gadamer mengilustrasikan bahwa teks mengumandangkan talāq bà'in atau talak tiga kali dengan pengarangnya. Dalam tradisi Islam, kematian sang pengarang (the death of the author) sangat bertubrukan dengan keyakinan dasar tentang wahyu sendiri.

Inilah sebetulnya yang menjadi masalah utama dalam perdebatan mengenai hermeneutika dan kaitannya dengan penafsiran al-Qur'ān. Yang diinginkan adalah bagaimana menarik manfaat dari dua konsep atau teori tersebut. Menekankan terlalu keras pada makna obyektifitas teks akan mengakibatkan makna teks tidak relevan bahkan akan cenderung vakum dan akan ditinggalkan oleh pembacanya, mengingat kajian yang disajikan sudah usang dan basi. Dan jika memberikan ruang yang terlalu luas pada makna subyektifitas penafsir dengan tidak memperhatikan makna obyektif akan menimbulkan penafsiran liar dan berpotensi terhadap pengkebirian makna yang dikehendaki pengarang dan pembiakan makna yang dikehendaki penafsir.

Pertanyaan yang mencuat dalam benak penulis adalah apakah ilmu tafsir belum cukup? Harus diakui bahwa teori-teori hermeneutika secara dasar bisa ditemui dalam karya tafsir klasik. Semisal kitab Tafsir al-Jalālain ${ }^{54}$, merupakan langkah awal dari analisa kebahasaan yang menjadi salah satu unsur kerja hermeneutika. ${ }^{55}$

Dalam kitab tafsir itu didefinisikan bahwa tafsir adalah usaha menjelaskan makna firman Allah sesuai dengan kemampuan manusia. Di sini tersimpan satu pengertian bahwa apa yang dihasilkan oleh ulama tafsir hanyalah sebuah upaya percobaan untuk menangkap makna atau kehendak Tuhan yang

Hamdi, "Hermeneutika Islam: Intertekstualitas, Dekontruksi dan Rekontruksi," 48.

${ }^{54}$ Tafsir ini dikatagorikan sebagai tafsir mujmal oleh kalangan pakar ilmu tafsir. Bermula dari surah al-Baqarah sampai surah akhir surah al-Isrā' ditulis oleh Jalāl al-Dīn

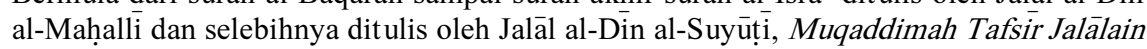
(Surabaya: Al-Hidayah, tt), 2.

55 Machasin, "Sumbangan Hermeneutika terhadap Ilmu Tafsir," 126. Muhammad

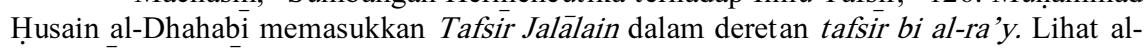
Dhahabi, al-Tafsìr wa al-Mufassirūn, Juz I, 220. 
terbingkai dalam teks suci al-Qur'ān. Percobaan itu dilakukan dan diukur kebenarannya sejauh mana manusia mampu melakukannya. Dalam uji coba itu, tentu ada hal yang ikut mempengaruhi yaitu penjara kebudayaan dan cara berfikir yang berbeda-beda. Wajar, satu ayat bisa beragam penafsiran karena perbedaan orang yang memahami.

Argumen yang dilontarkan mengenai kewajiban perempuan berjilbab bisa beragam dan logis. Ada yang mengatakan perempuan wajib berjilbab hanya dipakai untuk kerja supaya tidak mengganggu teman kerja laki-laki; ada yang berpendapat bahwa wajib dipakai di manapun saja. Semua itu bertumpu pada satu teks al-Qur'ān yaitu surah al-Aḥāa: 33. Lalu apa yang harus penafsir hadapi dan sikapi ketika ada multi penafsiran semacam ini. Hermeneutika mengajak seseorang untuk mencurigai dirinya sendiri, apakah penafsiran terhadap teks itu sudah akurat atau belum?

Mengutip pandangan Paul Ricoeur (1. 1913) tentang filsafat kedirian (selfhood) bahwa manusia bertolak dari relativitas sebuah penafsiran dengan mengemukakan empat aspek: siapa yang berbicara? Siapa yang bertindak? Siapa yang menceritakan sesuatu? dan siapa yang merupakan subyek moral dari tanggung jawab. Pertanyaan-pertanyaan ini bukanlah pertanyaan abstrak akan tetapi sebuah cara konkrit manusia menanyakan tentang dirinya sendiri. ${ }^{56}$

Kecurigaan itu harus selalu ditampilkan dalam setiap penafsiran sebab apa yang tampak terang benderang karena kebenderangannya, kadang kala hanya sebuah ilusi. Kecurigaan ini akan membawa pada sikap hati-hati dan mawas diri, terhindar dari truth claim dan pemerkosaan terhadap kebenaran dengan menistakan keragaman makna dan penafsiran. Sederhananya, dalam contoh pendahuluan muṣalli yuṣalli fi al-muṣallā bagi kalangan pembaca sudah mafhum dan maklum, tapi seorang ahli hermenutika akan mengambil jarak dan melakukan penelisikan-penelisikan secara seksama.

${ }^{56} \mathrm{~K}$. Bertens, Filsafat Barat Kontemporer, Jilid II (Jakarta: Gramedia Utama Press, 2001), 278. Lihat Fahruddin Faiz, Hermeneutika al-Qur'ān: Tema-tema Kontroversial, 10. 
Metode Tematik: Upaya Penafsiran secara Holistik ${ }^{57}$

Berangkat dari tujuan mulia yaitu untuk mengembalikan al-Qur'ān sebagai petunjuk bagi umatnya, metode penafsiran ulama kontemporerpun sedikit banyak berbeda dengan para ulama atau mufassir sebelumnya. Kalau para ulama sebelumnya lebih banyak cenderung menggunakan penafsiran dengan metode atau tehnik pencapaian analitis (tahlili $\overline{1}$, yaitu tafsir yang mengungkap ayat-ayat al-Qur'ān dengan memaparkan segala makna dan aspek yang terkandung di dalamnya sesuai urutan bacaan yang terdapat di dalam mushaf al-Qur'ān, ${ }^{58}$ maka dalam masa kontemporer para ulama menggunakan metode tematik (mauḍ $\bar{u} \bar{i}$ ) yaitu penafsiran yang berpijak pada satu tema tertentu. Metode tematik nampaknya metode yang paling banyak diminati oleh para penafsir kontemporer. Sesuai dengan namanya, metode tematik adalah sebuah upaya menafsirkan al-Quran dengan memfokuskan pada judul atau tema yang telah ditetapkan, hingga terhindar dari bertele-tele. Topik inilah yang menjadi ciri utama dari metode tematik. ${ }^{59}$

Tafsir tematik ditengarai sebagai metode alternatif yang paling sesuai dengan kebutuhan umat saat ini. Selain diharapakan dapat memberi jawaban atas pelbagai problematika umat, metode tematik dipandang sebagai yang paling obyektif. Sebab melalui metode ini seolah penafsir mempersilahkan alQur'ān berbicara sendiri menyangkut berbagai permasalahan. Istantiq al-qur'ān (ajaklah al-Qur'ān berbicara), demikian ungkapan yang sering dikumandangkan

${ }^{57}$ Tafsir tematik, secara istilah yaitu memberikan pengertian: menghimpun seluruh ayat al-Qur'ān yang memiliki tujuan dan tema yang sama. Kemudian, disusun berdasarkan kronologi turunnya dengan memperthatikan sebab-sebab turunya. Langkah berikutnya adalah dengan menguraikan dengan menjelajah seluruh aspek yang bisa digali. Hasilnya diukur dengan teori-teori yang akurat sehingga mufassir dapat menyajikan tema dengan utuh dan sempurna. Bersamaan dengan itu, dikemukakan pula tujuannya yang menyeluruh dengan ungkapan yang mudah dipahami sehingga bagianbagian terdalam sekalipun bisa diselami dan dipahami. Lihat al-Farmāwí, al-Bidayah fi al-Tafsis al-Mauḍu' $\bar{i}$, ter. Rosihan Anwar (Kairo: al-Hadārah al-'Arabiyah, 1977), 44. Lihat juga Muhammad Mạ̣mūd Ḥijāzì, Al-Waḥdah al-Mauḍ̄'iyyah fì al-Qur'ān alKarim, 25.

${ }^{\Sigma 8}$ Muhammad Quraish Shihab dkk., Sejarah dan 'Ulüm al-Qur'ān (Jakarta: Pustaka Firdaus, 2001), cet. ke-3, 172-192. Lihat juga: Ahmad Syukri Saleh, Metodologi Tafsir al-Qur'ān Kontemporer dalam Pandangan Fazlur Rahman (Jakarta: Sulthan Thaha

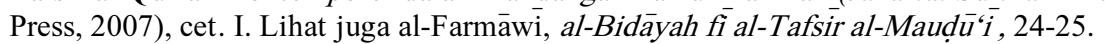

${ }^{59}$ Abdul Mustaqim, Aliran-aliran Tafsir: Madzahibut Tafsir dari Periode Klasik hingga Kontemporer, 83. Bandingkan dengan Muhammad Quraish Shihab, dkk., Sejarah dan 'Ulūm al-Qur'ān, 192-193 dan Muștafā Muslim, Mabāhith fi al-Tafsìr al-Mauḍù ‘' (Damaskus: Dār al-Qalam, 1989), 15-16. 
para pendukung metode ini. ${ }^{60}$ Dalam metode ini, penafsir yang hidup di tengah realita kehidupan dengan sejumlah pengalaman manusia duduk bersimpuh di hadapan al-Qur'ān untuk berdialog, mengajukan persoalan dan berusaha menemukan jawabannya dari al-Qur'ān.

Dikatakan obyektif karena sesuai maknanya. Kata al-mauḍ̄' berarti sesuatu yang ditetapkan di sebuah tempat, dan tidak ke mana-mana. Seorang mufassir yang menggunakan metode maw $\bar{u}^{6} \bar{i}^{-}{ }^{61}$ ketika menjelaskan pesanpesan al-Qur'ān terikat dengan makna dan permasalahan tertentu yang terkait, menetapkan setiap ayat pada tempatnya. Kendati kata al-mauḍ $\bar{u}$ ‘ dan derivasinya sering digunakan untuk beberapa hal negatif seperti hadis palsu (hadith mauḍu $\bar{u}^{\circ}$ ), atau tawậ̣u $u^{\star}$ yang asalnya bermakna al-tadhallul (terhinakan), tetapi dari 24 kali pengulangan kata ini dan derivasinya kita temukan juga digunakan untuk hal-hal positif seperti peletakan Ka‘bah (QS. Ali 'Imrān : 96), timbangan (QS. al-Raḥmān: 7) dan benda-benda surga (QS. alGhāshiyah: 13 dan 14). ${ }^{62}$ Dengan demikian tidak ada hambatan psikologis untuk menggunakan istilah ini (al-tafsir al-mauḍu $\bar{u} \cdot \bar{i}$ ) seperti dikhawatirkan oleh seorang pemuka tafsir tematik, dosen di Universitas al-Azhar, 'Abd al-Sattār Fathullāh. ${ }^{63}$

Hassan Hanafi (1. 1935 M) meletakkan pondasi filosofis tafsir tematik. Dikatakan bahwa wahyu diletakkan dalam beberapa bagian yang tidak diafirmasi atau dinegasi. Penafsir tidak dituntut untuk menjawab pertanyaan yang diperdebatkan oleh kalangan orientalis abad XIX yaitu tentang orsinalitas al-Qur'ān, apakah dari Allah atau Muhammad. Namun, metode tematik menafsirkan teks al-Qur'ān yang sudah ada tanpa harus mempertanyakan asal muasal teks tersebut. Artinya bahwa tafsir tematik memulai penafsirannya setelah turunnya kitab. Tafsir tematik tidak berkewajiban untuk melacak

${ }^{60}$ Lihat M. Bāqir al-Ṣadr, Al-Madrasah al-Qur'āniyyah (Qum : Shareat, Cet. III, 1426 H), 31. Ungkapan Istantiq al-Qur'ān terambil dari Imam Ali bin Abi Talib dalam kitab Nahj al-Balāghah, Khutbah ke 158, yang mengatakan : Dhālika al-Qur'ān Fastantiqūhu (Ajaklah al-Qur'ān itu berbicara). Lihat juga Mukhlis Hanafi, "Menggagas Tafsir Tematik Kolektif," Makalah Disampaikan pada Musyawarah Kerja Ulama alQur'ān se-Kalimantan dan Sulawesi di Gorontalo, 21-23 Mei 2007, 1.

G1 Para ulama yang menggagas metode ini berbeda pendapat dalam soal penamaannya. M. Bāqir al-Ṣadr menamakannya dengan metode tawhì $\bar{i}$ (penyatuan tema pembahasan), yang tahli $\bar{i} \bar{i}$ beliau sebut tajzí $\bar{i}$. Shaikh M. al-Ghazāi menyebutnya dengan

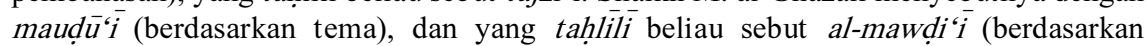
tempat/ urutan penyebutan dalam mushaf). Lihat Mukhlis Hanafi, "Menggagas Tafsir Tematik Kolektif," 1.

${ }^{62}$ Lihat al-Rāghib al-Așfahānī, Al-Mufradāt fì Gharīb al-Qur'ān, Juz I (Libanon: Dar al-Ma'rifat), 526.

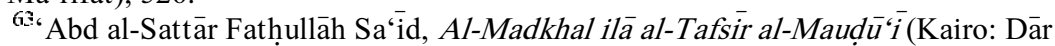
al-Nashr wa al-Tawzi`‘ al-Islāmiyyah, Cet. 2, 1991), 22. 
sumber teks tersebut. Dalam hal ini, teks adalah teks: $:^{54}$ historis atau ahistoris, sakral atau profan, relegius atau sekular. Pertanyaan seputar asal muasal alQur'ān adalah permasalahan genesis, sementara tafsir tematik hanya mempersoalkan esensi. ${ }^{65}$

Dalam tafsir tematik, al-Qur'ān diposisikan sebagai teks profan, yaitu sesuatu yang bisa ditafsirkan, sumber hukum, karya sastra, teks filosofis dan dokumen historis. Al-Qur'ān tidak dipandang sebagai sesuatu yang sakral dan teologis, jauh dari pernik-pernik interpretasi. Semua teks dimungkinkan mengikuti aturan interpretasi. Profan dan sakral tidak mendapatkan perbedaan dalam hermeneutika. Namun, dalam hal ini, al-Qur'ān telah menciptakan jenis sastra baru yang berada di tengah-tengah jenis sastra lama seperti puisi, dan atau prosa. Tafsir tematik juga tidak mengenai pemahaman yang benar atau salah, namun yang ada hanyalah perbedaan metodologis dalam mendekati teks (approach to a text) dengan berbagai kemungkinan dan kepentingan serta motif yang berbeda-beda. ${ }^{6 \sigma}$

\section{Urgensi Metode Tematik}

Metode penafsiran tematik ini menarik untuk dikembangkan karena mempunyai beberapa keunggulan dan keistemawaan yaitu pertama metode tematik mencoba memahami ayat-ayat al-Qur'ān sebagai satu kesatuan, ${ }^{67}$ tidak

${ }^{64}$ Menurut Ricoeur bahwa teks adalah wacana yang telah ditetapkan dalam bentuk tulisan, Komaruddin Hidayat mendefinisikan teks sebagai fiksasi atau pelembagaan sebuah peristiwa wacana lisan dalam bentuk tulisan yang bertujuan untuk melindungi dari kehancuran. Fiksasi ini bisa jadi dalam bentuk goresan pada batu, kulit hewan, pelepah kurma, tulang dan lain sebagainya. Dan dalam tradisi Islam, untuk menjaga atau melindungi teks dari kepunahan tidak hanya dengan menuangkan dan mengabadikan dalam bentuk tulisan, namun juga dalam bentuk hafalan-hafalan yang melekat di hati para penghafal (dàbit). Lihat Paul Ricoeur, Hermeneutics and Human Sciences, John B. Thomson (ed) (New York: Cambridge University, 1981), 145. Lihat juga Komaruddin Hidayat, Menafsirkan Kehendak Tuhan, 142 dan Muhammad ibn Muhammad Abū Shubhah, al-Madkhal Lì Dirāsat al-Qur'ān al-Karīm (Beirut: Dār alJail, 1992), cet I, 236-253.

${ }^{65}$ Hassan Hanafi, "Dari Teks ke Aksi: Merekomendasi Tafsir Tematik," terj. Eva Amrullah, dalam Jurnal Studi al-Qur'ān, Vol I No I Januari 2006, 66.

${ }^{66}$ Hassan Hanafi, "al-Wahy wa al-Wāqi': Dirāsat fì Asbāb al-Nuzūl," dalam Hassan Hanafi, al-Islām wa al-Hadāthah (London: Dār al-Sāqi, 1990), 133-175. Lihat juga Hassan Hanafi, "Dari Teks ke Aksi: Merekomendasi Tafsir Tematik," 67.

${ }^{67}$ Muhammad Abduh dalam beberapa karyanya menekankan kesatuan tema-tema al-Qur'ān, namun gagasan-gagasan itu baru diwujudkan oleh murid-muridnya seperti M. 'Abdullāh Dirāz dan Maḥmūd Shaltūt. Pendekatan hermeneutik Barat yang diadopsi oleh Amin al-Khūi $\bar{i}$ dalam ittijāh adabinya sebenarnya juga menitik beratkan pada pemahaman kesatuan teks-teks al-Qur'ann. Al-Khūli misalnya mengatakan bahwa penafsiran yang ideal adalah sebenarnya menafsirkan al-Qur'ān secara tematis, tidak menurut urutan mashaf. Lihat Mukhlis Hanafi, "Peta Literatur Tafsir dalam Tradisi 
parsial ayat perayat, sehingga memungkinkan memperoleh pemahaman terhadap tema dalam al-Qur'ān secara utuh. Metode tematik ini mengharuskan seseorang untuk memahami ayat-ayat al-Qur'ān secara proporsional, sehingga menempatkan ayat pada tempatnya. Dengan demikian, pemahaman ayat alQur'ān dengan model metode tematik ini akan berbeda secara diametral dengan model pemahaman sebelumnya yang cenderung parsial sehingga bisa menegasikan kesan pertentangan antar ayat. ${ }^{6 \mathrm{~s}}$

Kedua, metode tematik bisa langsung bersifat praktis, bisa langsung bermanfaat pada masyarakat karena masyarakat bisa memilih tema-tema tertentu untuk dikaji. Dengan metode tematik ini, seseorang bisa merujuk langsung pada al-Qur'ān, berangkat dari tema yang ada. Metode ini bukan hanya dirasakan langsung manfaatnya dalam memberikan solusi terhadap problematika masyarakat akan tetapi juga lebih efisien karena mengenyampingkan ayat-ayat yang tidak berkaitan atau yang tidak relevan dengan obyek yang dikaji tersebut. ${ }^{69}$

Ketiga, metode tematik bisa menghantarkan langsung pada pokok permasalahan tanpa harus bersusah payah seperti metode analitis (tahli $\bar{i} \bar{i})$, yang masih sering terjebak dalam kajian linguistik atau fiqh, apalagi dalam masa kekinian, yang membutuhkan penyelesaian secara cepat dan tepat. Mengutip perkataan Ahmad Sayyid al-Kummī bahwa metode tematik adalah metode penafsiran yang dapat menghantarkan untuk menemukan jawaban dari permasalahan dengan cepat dan tepat. Cepat karena langsung menukik pada topik pembahasan dan tepat karena ayat-ayat yang ditafsirkan adalah ayat-ayat yang berkaitan dengan pokok pembahasan. ${ }^{70}$

Keempat, metode tematik ini relevan dengan tuntutan zaman modern yang mengharuskan pada perumusan hukum-hukum yang bersifat universal, bersumber langsung pada al-Qur'ān bagi seluruh negara Islam, hingga mampu keluar dari jeratan sekte-sekte atau madhahib yang mengkungkung selama ini. ${ }^{71}$

Keilmuan: Klasik dan Modern," Makalah untuk Peserta Pendidikan Kader Mufassir angkatan IV Pusat Studi al-Qur'ān Jakarta, 2009, 10.

${ }^{68}$ Lihat Mustafá Muslim, Mabāhith fi al-Tafsir al-Maudū $\bar{i}, \bar{i}, 30-33$. Lihat Abdul Mustaqim, Aliran-Aliran Tafsir: Madzahibut Tafsir dari Periode Klasik hingga

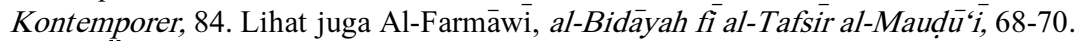

${ }^{69}$ Abdul Mustaqim, Aliran-Aliran Tafsir: Madzahibut Tafsir dari Periode Klasik hingga Kontemporer, 85. Lihat juga Al-Farmāwi, al-Bidāyah fī al-Tafsir al-Mauḍù ‘, $\bar{i}, 68-$ 70 .

${ }^{70}$ Lihat M. Quraish Shihab, Wawasan al-Qur'ān: Tafsir Tematik atas Pelbagai Persoalan Umat (Jakarta: Mizan, 2007), xii.

${ }^{71}$ Lihat Muh. 'Alī al-Riḍ̂a'i al-Aṣfahānī, Manāhij al-Tafsìir wa Ittijāhuh, 402. Lihat juga Al-Farmāwìi, al-Bidàyah fì al-Tafsì al-Mauḍu' $\bar{i} \bar{i}, 80$. Bandingkan dengan

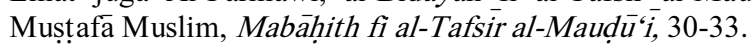




\section{Memotret Geneologi Metode Tematik}

Al-Farmāwi berpandangan bahwa sesungguhnya al-Qur'ān telah menghimpun tema-tema yang perlu digali dengan menggunakan metode tematik. Artinya bahwa didalam al-Qur'ān terdapat kesinambungan dan ketidak terputusan antara ayat yang satu dengan lainnya. Seandainya digali dengan serius dan mendalam maka mukjizat al-Qur'ān, yaitu sebagai petunjuk kepada umatnya (hudan li al-nās) akan tercapai yang di antaranya adalah penetapan syariat yang sesuai dengan perubahan dinamika kehidupan kekinian. ${ }^{72}$

Geneologi penggunaan metode tematik sebagai metode dalam menafsirkan al-Qur'ān bisa ditemukan dalam beberapa karya ulama sebelumnya, semisal al-Bayān fì Aqsām al-Qur'ān karya Ibn al-Qayyim alJauziyah (691-751/1292-1350), Majāz al-Qur'ān karya Abū Ubaidah, Mufrdàt al-Qur'ān karya al-Rāghib al-Aṣfahāni, al-Nāsikh wa al-Mansūkh karya Abū Ja'far al-Nuḥ̣̂ās, Asbāb al-Nuzūl karya al-Wāhidi, Aḥkām al-Qur'ān karya alJașṣāṣ.

Jika karya-karya di atas ditelisik secara seksama, akan ditemukan satu benang merah dengan metode tematik yang berkembang saat ini, yaitu, pertama bahwa al-Wāhidi berusaha untuk menghimpun ayat-ayat yang turun dengan sebab-sebab tertentu. Kedua, Abū Ja'far berusaha semaksimal mungkin untuk melacak dan kemudian menghimpun ayat-ayat yang dihapus dan yang menghapus dan ketiga, AbūUbaidah juga melakukan hal yang sama, yaitu mengadakan investigasi terhadap ayat-ayat atau redaksi -redakasi yang mengandung unsur-unsur majaz. Itu semua, menurut pandangan 'Ali Khalil adalah satu signal bagus dari nabi Muhammad saw yang menunjukkan bahwa ketidak jelasan dalam al-Qur'ān dapat diselesaikan dengan melihat ungkapan lain dalam ayat yang lain. Dengan kata lain, benih metode tafsir tematik sudah ada sejak era klasik. ${ }^{73}$

Namun, signal dari nabi Muhammad saw itu belum disambut dengan baik oleh para penafsir terdahulu. Mereka lebih memilih untuk menafsirkan alQur'ān dengan berdasarkan urutan mashaf -- baik dengan metode global atau analitis -- menafsirkan al-Qur'ān ayat perayat dan surah persurah. Tujuan mereka adalah untuk menangkap dan mengungkapkan makna-makna dan rahasia al-Qur'ān dengan bantuan disiplin ilmu yang mereka miliki, hingga metode tematik yang benihnya telah diumpamkan nabi Muhammad saw kurang bisa ditangkap dengan cerdas dan tanggap.

Setidaknya, ada dua faktor mengapa hal itu terjadi yaitu, pertama sudah menjadi tradisi dari kalangan para mufassir terdahulu bahwa setiap penulisan

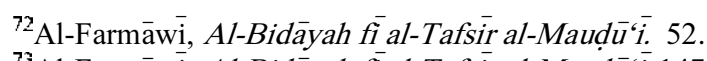

${ }^{73} \mathrm{Al}-\mathrm{Farmāw} \bar{i}$, Al-Bidāyah fì al-Tafsìr al-Mauḍù $\bar{i}, 147$. 
atau karya terutama tafsir ingin mengungkapkan seluruh makna yang terkandung dalam al-Qur'ān. Kecenderungan untuk lebih fokus pada tema (almaud $\left.\bar{u}^{`}\right)$ belum menjadi trend kala itu, sehingga tradisi global dan tahlili menjadi menu alternatif metode penafsiran saat itu. Kedua kebutuhan pada waktu itu belum menuntut secara mendesak untuk menggunakan metode tematik, sehingga mereka tidak menyentuh untuk menelaan al-Qur'ān dengan berdasarkan dan berpijak pada tema-tema tertentu. ${ }^{74}$

Kondisi ini berbeda dengan keadaan sekarang. Para penafsir tidak mungkin mencapai tujuan mulia al-Qur'ān dengan menggunakan produk metode global atau analitis, karena beberapa alasan. Pertama sirkulasi dan dinamika kehidupan global semakin pesat dan cepat, tentu menghasilkan efek atau problem yang complecated dan perlunya diselesaikan dengan pemecahan yang cepat dan akurat. Mustahil, problem itu bisa dijawab dengan produk-produk yang dihasilkan oleh metode global (ijmāli) atau analitis (tahli $\bar{i} \bar{i})$. Tentu dibutuhkan metode yang praktis dan cepat. Metode alternatif yang relevan dengan kekinian adalah metode tematik (mauḍu'i) mengingat metode ini mengacu pada kesatuan tema yang dibutuhkan.

Kedua sebagian dari mereka tidak memiliki konfidensi, kualifikasi dan wawasan yang memadai untuk mengkaji al-Qur'ān secara keseluruhan. Diharapkan, metode tematik bisa menghantarkan para penafsir untuk menghimpun tema-tema al-Qur'ān hingga menjadi satu kesatuan yang sempurna. Ketiga mereka tidak memiliki wawasan kebudayaan Islam yang mampu mendorong mereka untuk melakukan kajian-kajian keislaman secara utuh dan luas sebagai bekal mengarungi hidupnya. Wajar kalu mereka bingung mencari jalan yang benar. Di sinilah metode tematik, menemukan momentumnya. ${ }^{75}$

Keempat pada era sekarang, marak sekali, baik dari kalangan muslim atau orientalis yang mengadakan kajian (research) terhadap al-Qur'ān (Qur'ānic studies) dengan berpijak dan berangkat dari tema-tema tertentu. Namun, karena tidak dibarengi oleh kemampuan atau kualifikasi keilmuan yang mewadai, seringkali menghasilkan konklusi yang justru "mengusik" keberimanan orang muslim. Di sinilah, perlunya membuat metode yang mampu memberikan pencerahan dalam hal memahami al-Quran sehingga tujuan mulia, sebagaimana yang disinggung oleh Muhammad 'Abduh (1849-1905 M) bisa terealisasi. ${ }^{76}$

${ }^{74}$ Aḥmad Mahnan, Al-Insān fī al-Qur'ān al-Karìm (Beirut; Dār al-Fikr, tt), 10.

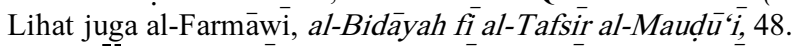

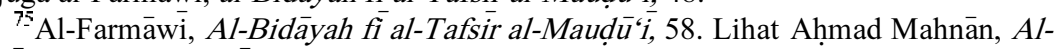
Insān fì al-Qur'ān al-Karìm, 11.

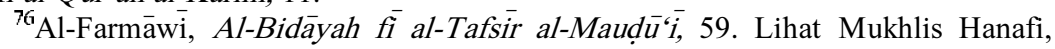
"Menggagas Tafsir Tematik Kolektif," 8. 


\section{Penutup: Integrasi Penafsiran Antara Hermeneutika dan Metode Tematik}

Harus diakui bahwa khazanah 'ulūm al-Qur'ān sebagai seperangkat metodologi penafsiran dan pemaknaan terhadap al-Qur'ān memiliki sofistifikasi yang tinggi. Bagaimana tidak, dari 'ulūm al-Qur'ān ini terbukti telah lahir berlimpahnya karya-karya tafsir dengan berbagai metode dan menghasilkan penafsiran yang beragam. Mulai dari metode analisis hingga metode tematik; tafsir yang bercorak esoterik hingga eksoterik. Ini semua membuktikan betapa 'ulūm al-Qur'ān yang telah memberikan kontribusi yang mapan dan luar biasa adalah satu disiplin keilmuan yang komprehensif dan holistik. Dari sinilah, kemudian timbul satu persepsi bahwa disiplin 'ulūm al-Qur'ān sudah cukup dan tidak membutuhkan metode lain terutama dari non muslim yang nota benenya tidak mempercayai kesucian al-Qur'ān. ${ }^{77}$

Apabila melihat asumsi-asumsi dasar hermeneutika di atas yaitu perhatian kepada tidak saja pada teks namun juga konteks, sebenarnya beberapa perangkat dan variable 'ulūm al-Qur'ān klasik telah menunjukkan orientasinya ke arah tersebut. Tema-tema seperti nāsikh mansūkh, asbāb al-nuzūl, dan makki-madani menunjukkan perhatian kepada adanya perbedaan konteks yang mempengaruhi pemaknaan. Sampai di sini, klaim bahwa 'ulūm al-Qur'ān masih memadai untuk mengolah dimensi pemaknaan terhadap al-Qur'ān harus diakui mempunyai relevansi. ${ }^{78}$

Namun demikian, mengutip pendapat Thomas S. Khun dalam bukunya, The Structure of Scientific Revolutions bahwa dalam rentang waktu tertentu, pergeseran dan perubahan teori dan metodologi dalam ilmu pengetahuan adalah sebuah keniscayaan yang merupakan tuntutan kesejarahan karakteristik suatu zaman, sehingga perubahan itu merupakan sesuatu yang tidak bisa dihindari. Oleh karenanya, Michael Focault ${ }^{79}$ menegaskan bahwa tugas memberi makna, termasuk terhadap teks suci tidak akan pernah selesai dan berhenti. Di samping

${ }^{77}$ Lihat Adnin Armas, "Pengaruh Metodologi Bibel terhadap Studi Alquran," Republika, 29 November 2004 dan Adnin Armas, "Tafsir Al-Qur'an atau 'Hermeneutika Al-Qur'an'," dalam Islamia 1, 1 (2004), 45 dan Ugi Suharto, "Apakah al-Qur'an Memerlukan Hermeneutika?" dalam Islamia 1, 1 (2004), 52. Lihat Yusuf Rahman, "Hermeneutika dan al-Qur'ān," makalah dalam bentuk soft copy, 3. lihat juga Nasaruddin Umar, "Menimbang Hermeneutika Sebagai Manhaj Tafsir," 46.

${ }^{78}$ Lihat Fahruddin Faiz, Hermeneutika al-Qur'ān: Tema-tema Kontroversial, 1819.

${ }^{79}$ Michael Focault, The Order of Things on Archeology of the Human Sciences (New York: Vintage Books, 1994), 41. Lihat al-Makin,”Apakah Tafsir Masih Mungkin?", dalam Abdul Mustakim dan Sahiron Syamsuddin (ed.), Studi al-Qur'an Kontemporer: Wacana Baru Berbagai Metodologi Tafsir (Yogyakarta: Tiara Wacana, 2002), 3 dan lihat H. M. Yusron, Studi Kitab Tafsir Kontemporer (Yogyakarta: Teras, 2006), vi. Bandingkan dengan Gadamer, Truth and Method, trans. Joel Weinshemer dan Donald G. Marshall (New York: Continum,1997), 296. 
itu, faktor internal yang dimiliki manusia yang merupakan karakteristik manusia (al-tabi $\left.{ }^{`} a h\right)$ yaitu keingintahuan yang besar terhadap segala yang ada menjadi pemicu yang menggerakkan untuk melahirkan satu pengetahuan baru. ${ }^{80}$

Menggunakan metode tematik dalam memaknai al-Qur'ān akan lebih baik bila diintegrasikan dengan pendekatan hermeneutik. Perdebatan seputar apakah hermeneutik sah dijadikan instrumen dalam penafsirkan, menurut penulis, sudah usang. Sebab pendekatan atau metodologi apapun yang mampu menangkap makna al-Qur'ān sehingga adigium besar al-Qur'ān yaitu șāliḥun likulli zamānin wa makānin tercapai. Maka dengan sendirinya, pendekatan dan metodologi tersebut adalah bagian dari 'ulūm al-Qur'ān.

\section{Daftar Pustaka}

'Abd al-Hamīd, Muḥsin. Haqūiat al-Bābiyah wa al-Baha'iyah. Kairo: Dār alSahwah, 1985.

Abdul Mustaqim. Aliran-Aliran Tafsir: Madzahibut Tafsir dari Periode Klasik hingga Kontemporer. Yogyakarta: Kreasi Wacana, 2005.

Abū Shubhah, Muhammad ibn Muhammad. Al-Madkhal Lì Dirāsat al-Qur'ān al-Karìm. Beirut: Dār al-Jail, 1992.

Abū Zayd, Naṣr Hạamid. Hermeneutika Inklusif. Terj. Muh. Mansur dkk. Jakarta: ICIP, 2004.

. Mafhūm al-Nāṣs : Dirāsah fī 'Ulūm al-Qur'ān. Kairo: al-Hay'ah alMiṣriyah al-‘Ammah li al-Kitāb, 1993.

Armas, Adnin. "Pengaruh Metodologi Bibel terhadap Studi Alquran." Republika, 29 November 2004.

-------. "Tafsir Al-Qur'an atau 'Hermeneutika Al-Qur'an'.” Dalam Islamia 1, 1 (2004).

-. Metodologi Bibel dalam Studi al-Qur'ān. Jakarta: Gema Insani Press, 2006.

al-Aṣfahāni, al-Rāghib. Al-Mufradāt fī Gharīb al-Qur'ān. Juz I. Libanon: Dar alMa'rifat.

al-Aṣfahānī, Muh. 'Ali al-Riḍāì. Manāhij al-Tafsīir wa Ittijāhuh : Dirāsah Muqaranah fì Manahij Tafsir al-Qur'ān al-Karim. Beirut: Markaz alHaḍarah li-Tanmiyati al-Fikri, 2007.

${ }^{80}$ Lihat Thomas S. Khun dalam bukunya, The Structure of Scientific Revolutions (Chicago: The Universsity of Chicago Press, 1970), 201. Lihat juga Muhammad Mansur, "Amin al-Khuli dan Pergeseran Paradigma Tafsir al-Quran," dalam Jurnal Studi ilmuilmu al-Quran dan Hadits, Vol.6, No. 2, Juli 2005, 209, dan lihat Yusron, Studi Kitab Tafsir Kontemporer, vi. 
Badawī, 'Abd al-Raḥmān. Mausū'ăt al-Mustashriqin. Terj. Amroeni Derajat. Ensiklopedi Tokoh Orientalis. Yogyakarta: LkiS, 2003.

Bertens, K. Filsafat Barat Kontemporer: Inggris dan Jerman. Jakarta:Gramedia, 2002.

al-Dhahabī, Muhammad Husain. Al-Tafsìir wa al-Mufassirūn. Jilid I. Kairo: Dār al-Kutub al-Hadithah, 1961.

Dilthey, Wilhelm. "The Hermeneutics of the Human Sciences." Dalam Kurt Muller-Vollmer (ed). The Hermeneutics Readers. New York: The Publishing Company, 2002.

Faiz, Fahruddin. Hermeneutika al-Qur'ān: Tema-tema Kontroversial. Yogyakarta: eLSAQ Press, 2005.

al-Farmāwì, 'Abd al-Hayy. Al-Bidāyah fì al-Tafsir al-Mauḍu' $\bar{i}$. Ter. Rosihan Anwar. Kairo: al-Hadūāah al-'Arabiyah, 1977.

Federspiel, Howard. Kajian al-Qur'ān di Indonesia. Jakarta: Mizan, 1996.

Focault, Michael. The Order of Things on Archeology of the Human Sciences. New York: Vintage Books, 1994.

Gadamer, Hans-Georg. Truth and Method. Trans. Joel Weinshemer dan Donald G. Marshall. New York: Continum,1997.

Goldziher, Ignaz. Madhāhib al-Tafsìir al Islāmī. Beirut: Dār al-Iqra', 1983.

Hamdi, A. Zainul. "Hermeneutika Islam: Intertekstualitas, Dekontruksi dan Rekontruksi." Journal Gerbang. Vol V no 14, 2003.

Hanafi, Hassan. "al-Wahy wa al-Wāqi': Dirāsat fì Asbāb al-Nuzūl." Dalam Hassan Hanafi, al-Islām wa al-Hadāthah. London: Dār al-Sāqi, 1990.

-------- "Dari Teks ke Aksi: Merekomendasi Tafsir Tematik." Terj. Eva Amrullah. Jurnal Studi al-Qur'ān. Vol I No I Januari 2006.

Hanafi, Mukhlis. "Menggagas Tafsir Tematik Kolektif.” Makalah Disampaikan pada Musyawarah Kerja Ulama al-Qur'ān se-Kalimantan dan Sulawesi di Gorontalo, 21-23 Mei 2007.

-------. "Peta Literatur Tafsir dalam Tradisi Keilmuan: Klasik dan Modern." Makalah untuk Peserta Pendidikan Kader Mufassir angkatan IV Pusat Studi al-Qur'ān Jakarta, 2009.

Hidayat, Komaruddin. Memahami Bahasa Agama, Sebuah Kajian Hermeneutik. Jakarta: Paramadina, 1996.

Ibn 'Abd al-Raḥmān, Fahd. Uṣūl al-Tafsīir wa Manāhijuh. Riyāḍ: alTaubah, 1413H.

Ibn Rushd. Bidāyat al- Mujtahid. Juz I. Kairo: Maktabah Kulliyah alAzhar,1969.

Ibn Taimiyah. Muqaddimah fī Ușūl al-Tafsìir. Ed. 'Adnān Zarzūr. Kuwait: Dār al-Qur'ān, 1971/1391.

Ichwan, M. Nur. Meretas Kesarjanaan al-Qur'an, Teori Hermeneutika Naṣr Hāmid Abū Zayd. Jakarta: Teraju, 2003. 
--------. “Al-Qur'ān sebagai Teks (Teori Teks dalam Hermeneutika al-Qur’ān Naṣr Hāmid Abū Zayd)." Dalam Abdul Mustakim dan Sahiron Syamsuddin (ed). Studi Al-Qur'ān Kontemporer, Wacana Baru berbagai Metodologi Tafsir. Yogyakarta: Tria Wacana, 2002.

Al-Jazīri, 'Abd al-Raḥmān. al-Fiqh 'alā al-Madhāhib al-Arba'ah. Jilid I. Beirut: Dār al-Fikr, tt.

Khun, Thomas S. The Structure of Scientific Revolutions. Chicago: The University of Chicago Press, 1970.

Machasin. "Sumbangan Hermeneutika terhadap Ilmu Tafsir." Jurnal Gerbang: Journal Studi Agama dan Demokrasi. Vol 5, No 14

Madjid, Nurcholish. Islam Doktrin dan Peradaban. Jakarta: Paramadina, 2000.

al-Maḥalli, Jalāl al-Dīn dan Jalāl al-Dīn al-Suyūtị. Tafsìr Jalālain. Surabaya: AlHidayah, tt.

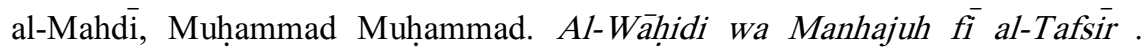
Kairo: Jumhuriyah Miṣr al-'Arabiyyah Wizārat al-Auqāf, tt.

Mahnan, Aḥmad. Al-Insān fī al-Qur’ān al-Karīm. Beirut; Dār al-Fikr, tt.

al-Makin."Apakah Tafsir Masih Mungkin?". Dalam Abdul Mustakim dan Sahiron Syamsuddin (ed.). Studi al-Qur'ān Kontemporer: Wacana Baru Berbagai Metodologi Tafsir. Yogyakarta: Tiara Wacana, 2002.

al-Malikī, Muhammad 'Alwī. Al-Qawā'id al-Asāsiyyah fī 'Ulūm al-Qur'ān. Mekkah: Maktabah Fahd, tt.

Mansur, Ali “Ahli Kitab dalam Al-Qur'ān (Model Penafsiran Fazlur Rahman).” Dalam Abdul Mustakim dan Sahiron Syamsuddin (ed.). Studi Al-Qur'ān Kontemporer, Wacana Baru berbagai Metodologi Tafsir. Yogyakarta: Tria Wacana, 2002.

Mansur, Muhammad. “Amin al-Khuli dan Pergeseran Paradigma Tafsir alQuran.” Dalam Jurnal Studi ilmu-ilmu al-Quran dan Hadits. Vol.6, No. 2, Juli 2005.

Maulidin. "Sketsa Hermeneutika." Dalam Gerbang: Journal Studi Agama dan Demokrasi. Vol 5, No 14.

Muslim, Muștafā. Mabāhith fi al-Tafsìir al-Mauḍū'ì Damaskus: Dār al-Qalam, 1989.

Nashshār, 'Alì Sāmī. Manāhaj al-Baḥth 'inda Mufakkirī al-Islām. Beirut: Dār alNahḍah al-'Arabiyah,tt.

Nasution, Harun. Islam Ditinjau dari Berbagai Aspeknya. Jilid II. Depok:UI Press, 2002.

-------. Islam Rasional: Gagasan dan Pemikiran Prof. Dr. Harun Nasution. Cet. V. Jakarta: Mizan, 1998.

Noer, Kautsar Azhari. “Aliran-aliran Islam Kontemporer." Makalah Mata Kuliah Analisa Pemikiran Islam Kontemporer Sekolah Pascasarjana UIN Syarif Hidayatullah, 16-09-2008. 
al-Qaț̣̄ān, Mannā'. Mabāḥith fi 'Ulūm al-Qur'ān. Riyaḍ: Maktabah Dār alHadith, 1973.

al-Qurțūbì, Abū Abdillāh Muhammad. Al-Jāmi` li Aḥkām al-Qur’ān. Juz I. Beirut: Dār Ihȳā', 1967.

Rahman, Fazlur. Metode dan Alternatif NeoModernisme Islam. Terj. Taufik Adnan Amal.

Rahman, Yusuf. "Hermeneutika dan al-Qur'ān.” Makalah mata kuliah Pendekatan dan Metodologi Studi Islam Sekolah Pascasarjana UIN Syarif Hidayatullah Jakarta.

Raya, Ahmad Thib. Rasionalitas Bahasa al-Qur'ān: Upaya Menafsirkan alQur'ān dengan Pendekatan Bahasa. Jakarta: Fikra, 2006.

Ricoeur, Paul. Hermeneutics and Human Sciences. John B. Thomson (ed). New York: Cambridge University, 1981.

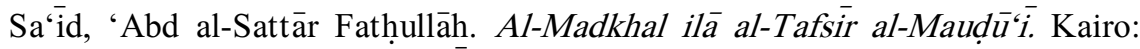
Dār al-Nashr wa al-Tawzī'al-Islāmiyyah, Cet. 2, 1991.

Sābiq, Sayyid. Fiqh al-Sunnah. Vol II. Kairo: Dār al-Qalam, 1995.

al-Ṣadr, M. Bāqir. Al-Madrasah al-Qur'āniyyah. Qum: Shareat, Cet. III, 1426 H.

Saeed, Abdullah. Interpreting the Qur'ān: Towards a Contemporary Approach. Oxford: Routledge, 2006.

Saenong, Faried F. "Kodifikasi Ulum al-Qur'ān hingga Abad Pertengahan: Studi Bibliografis.” Jurnal Studi al-Qur'ān. Vol I No I Januari 2006.

Saleh, Ahmad Syukri. Metodologi Tafsir al-Qur'ān Kontemporer dalam Pandangan Fazlur Rahman. Jakarta: Sulthan Thaha Press, 2007.

Schleiermacher, F. "Foundation: General Theory and Art of Interpretation." Dalam Kurt Muller-Vollmer (ed). The Hermeneutics Readers. New York: The Publishing Company, 2002.

Setiawan, M. Nur Khalis. al-Qur'an Kitab Sastra Terbesar. Yogyakarta: eLsAq Press, 2005.

-------. “Al-Qur'ān dalam Kesarjanaan Klasik dan Kontemporer.” Journal Studi al-Qur'ān. Vol I, No 1, Januari 2006.

Shaḥrūr, Muhammad. Al-Kitāb wa al-Qur'ān: Qirā'ah Mu'āsirah. Damaskus: alAhali, 1992.

-------. Naḥw al-Ușūl al-Jadidah Li Fiqh al-Islam. Damaskus: al-Ahali, 2000.

Shihab, M. Quraish. Wawasan al-Qur'ān: Tafsir Tematik atas Pelbagai Persoalan Umat. Jakarta: Mizan, 2007.

-------, dkk. Sejarah dan 'Ulūm al-Qur'ān. Jakarta: Pustaka Firdaus, 2001.

Sonn, Tamara. "Fazlur Rahman." Dalam John L. Esposito (ed). The Oxford Encyclopedia of the Modern Islamic World. Vol. 3. Oxford University Press, 1995.

Suharto, Ugi. “Apakah al-Qur'an Memerlukan Hermeneutika?” Dalam Islamia 1,1 (2004). 
Sumaryono, E. Hermeneutik: Sebuah Metode Filsafat. Yogyakarta: Kanisius, 1999.

Suryadilaga, Al-Fatih dkk. Metodologi Ilmu Tafsir. Yogyakarta: Teras, 2005.

al-Suyūți. Al-Itqān fī 'Ulūm al-Qur'ān. Juz IV. Ed. Muhammad Abū al-Faḍl Ibrāhim. Kairo: Madzhab Husaini, tt.

al-Ṭabarì. Jāmi' al-Bayān 'an Ta'wīl Āy al-Qur'ān. Juz I. Beirut: Dār al-Fikr, tt.

Tim Penulis Pusat Studi Al-Qur'ān. Kekerasan Atas Nama Agama. Jakarta: Lentera Hati, 2009.

Umar, Nasaruddin. "Menimbang Hermeneutika Sebagai Manhaj Tafsir." Journal Studi al-Qur'ān. Vol I, No 1, Januari 2006.

Warsidi, Slamet. "Hermeneutika Dialektik Spekulatif Hans Georg Gadamer: Aktualisasi serta Relevansinya dalam Kajian Teks Keagamaan.” Dalam Journal Filsafat Potensia (Fakultas Ushuluddin Sunan Kalijaga Yogyakarta), 2002.

Ya'qūb, Țāhir Maḥmūd Muhammad. Asbāb al-Khata’ fì al-Tafsīir. Juz I. Riyaḍ: Där Ibn Jauziyah, $1425 \mathrm{H}$.

Yusron, M. Studi Kitab Tafsir Kontemporer. Yogyakarta: Teras, 2006.

Zaghlūl, Muhammad Hamd. al-Tafsīì bi al-Ra’y: Qawā'iduh, Dawābițh, wa 'Alāmuh. Dimashq: Maktabah al-Farabi, 1999.

al-Zarkashī, Badr al-Dīn. Al-Burhān fī 'Ulūm al- Qur'ān. Juz 2. Kairo: 'Īsā al Halabì, $1374 \mathrm{H}$. 